\title{
Review
}

\author{
Meenakshisundaram Ganesan*, Nitin Trivedi, Vishal Gupta, S. Venu Madhav, \\ Chennur Radhakrishna Reddy* and Ira A. Levine
}

\section{Seaweed resources in India - current status of diversity and cultivation: prospects and challenges}

https://doi.org/10.1515/bot-2018-0056

Received 31 May, 2018; accepted 25 April, 2019; online first 13 June, 2019

\begin{abstract}
Seaweeds are an integral part of coastal ecosystems and offer invaluable ecosystem services supporting the life of many marine forms. The economic value of seaweeds significantly contributes to the sustainable development of rural coastal regions. Seaweeds are consumed as food in some Asian countries, but their utilization for production of phycocolloids is widespread across the globe, with an estimated value of more than one billion US\$. In India, seaweeds have been utilized exclusively for the production of phycocolloids but recently they are used for the production of plant growth stimulants for agricultural applications. The domestic agar and alginate industry totally depends on the supplies from natural seaweed beds with some occasional imports. The recent success achieved in both upstream and downstream technologies in production and processing of seaweeds has boosted the prospects for commercialization of seaweed resources in the country. The present article briefly appraises the current status of Indian seaweed resources and their utilization, as well as developments in seaweed farming technologies, the status of seaweed industry and recent efforts to transform seaweed farming into a social enterprise. It also highlights the
\end{abstract}

\footnotetext{
*Corresponding authors: Meenakshisundaram Ganesan, Marine Algal Research Station, Division of Biotechnology and Phycology, CSIR-Central Salt and Marine Chemicals Research Institute, Mandapam Camp 623519, India, e-mail: ganesan@csmcri.res.in; and Chennur Radhakrishna Reddy, DBT-ICT-Centre for Energy Biosciences, Institute of Chemical Technology, Matunga, Mumbai 400019, India, e-mail: crkcsmcri@gmail.com Nitin Trivedi: DBT-ICT-Centre for Energy Biosciences, Institute of Chemical Technology, Matunga, Mumbai 400019, India Vishal Gupta: Biological Oceanography Division, CSIR-National Institute of Oceanography, Dona Paula, Goa 403004, India S. Venu Madhav: Divine Chemtec Ltd., Visakhapatnam Special Economic Zone, Duvvada, Visakhapatnam 530049, India Ira A. Levine: University of Southern Maine, Lewiston, ME 04240, USA
}

challenges encountered for mainstreaming these resources so as to evolve into a marine industry.

Keywords: agar; alginate; cultivation; diversity; seaweed.

\section{Introduction}

In 2016-17, India produced over 270 million tonnes of food grains to feed more than 1.2 billion people (Anon 2017). This population is increasing year-on-year and, as it grows, demand for food grain production increases. Traditional Indian agriculture is currently at maximum production levels but lacks the capacity to fill the gap between production and demand. Furthermore, farmlands are put to more lucrative uses of land for building townships, industrial corridors, commercial establishments, infrastructural facilities, etc. Therefore, it is imperative that society must identify alternative resources that will support and supplement the long-term human food demands sustainably with minimal environmental impacts and associated biological phenomena. There is ample evidence of the importance of seaweeds in the context of human food needs and ecological benefits of farming (Craigie 2011, Cornish et al. 2017). Economic uses of seaweeds particularly for food, feed, phycocolloids and agro-based products, are well known for centuries and are now being extensively investigated for their application in bio-fuel, nutraceutical, medicinal, personal-care and food additive industries (Hafting et al. 2015, Kim et al. 2017).

Direct consumption of seaweeds as food in the form of salads, soups and a number of other food preparations is very common in Southeast Asian countries. Japan, China and Korea stand at the forefront of seaweed utilization in human food preparations, whereas in India, seaweeds are used only for the extraction of industrially important phycocolloids such as agar, alginate and carrageenan.

Global production of seaweeds has been estimated at 30.1 million wet tons in 2016 (FAO 2018), with 95\% of the 
total produced from culture and the remaining 5\% from natural beds. The top seven countries that account for global production of seaweeds are: China, Japan, Korea, Indonesia, Philippines, Malaysia and Vietnam. However, in India, agar and alginate are produced from seaweeds harvested from wild stocks whereas carrageenan is obtained from cultivated Kappaphycus alvarezii (Doty)Doty ex P.C. Silva.

The present review provides an overview of Indian seaweed resources, their utilization and the associated seaweed industry. Recent initiatives to develop and transform seaweed farming into social enterprises are described. Opportunities and challenges for building a successful seaweed industry in India are also discussed.

\section{Seaweed diversity}

India is among the 12 mega-biodiversity nations in the world. India's coastline is $8100 \mathrm{~km}$ long and has an
Exclusive Economic Zone (EEZ) of 2.17 million $\mathrm{km}^{2}$ (equal to $66 \%$ of total mainland area) (Figure 1). Nearly $30 \%$ of its human population is, one way or another, dependent on the rich exploitable coastal and marine resources. The Indian coastline, with its different coastal ecosystems, supports luxuriant growth of diverse seaweed populations, having considerable economic importance. The first report on seaweed diversity was published by Iyengar (1927) on the flora of Krusadai Island, Southeast coast of India. Subsequently, Boergesen (1928) investigated the seaweeds of the west coast and published a new record of Rosenvingea stellata Boergesen. Later Thivy (1948), Krishnamurthy (1957) and Umamaheswara Rao (1969) made substantial contributions to increase our knowledge of India's seaweed diversity. During 1980-1990, the Central Salt and Marine Chemicals Research Institute (CSMCRI) made a comprehensive survey and estimated the total seaweed standing stocks as 97,400 tonnes wet wt. from the coast of Tamil Nadu, 7500 tonnes wet wt. from

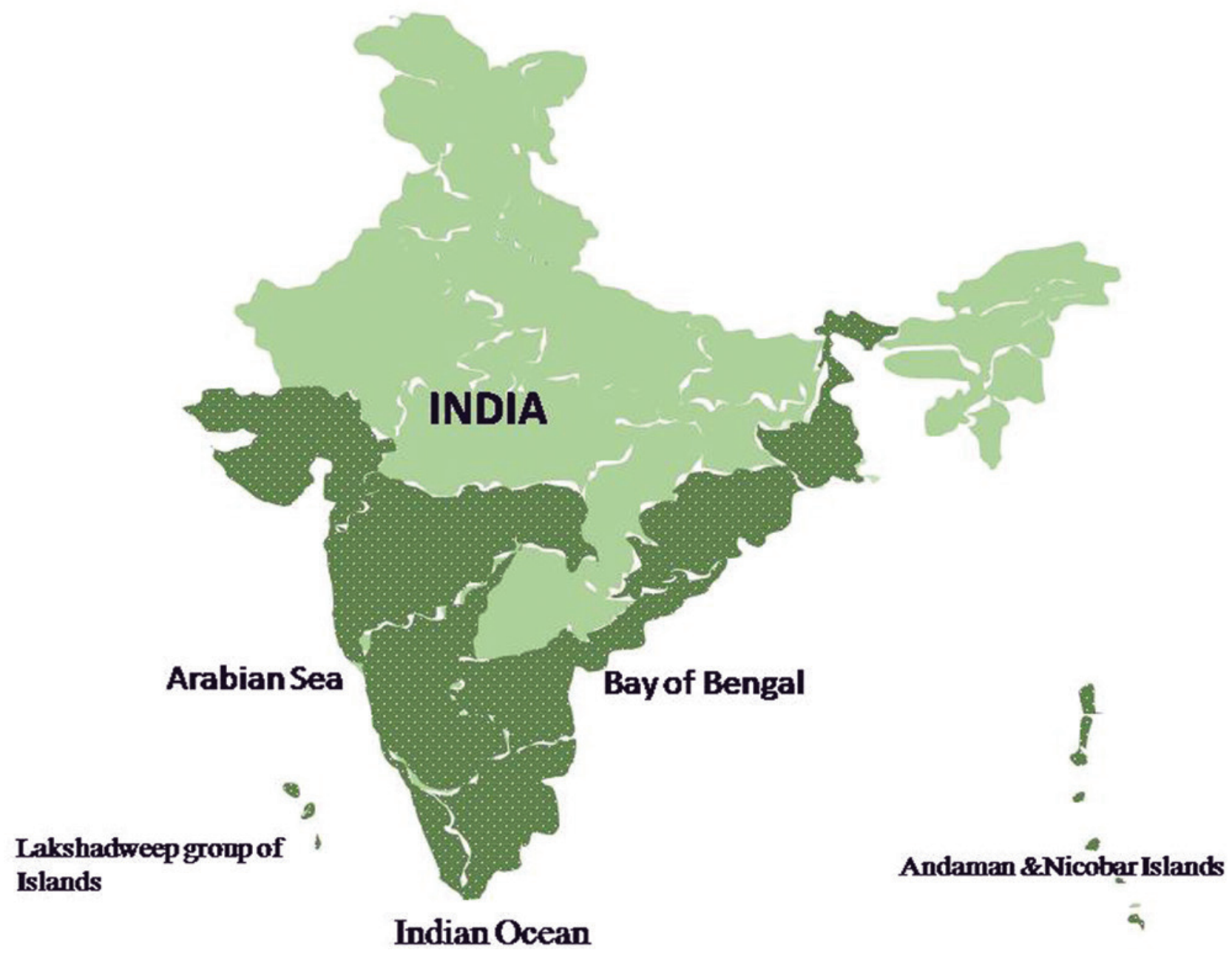

Figure 1: Map of Indian subcontinent. 
the coast of Andhra Pradesh and 19,345 tonnes wet wt. from the Lakshadweep islands (Kaliaperumal and Kalimuthu 1997). Oza and Zaidi (2001) updated the checklist of seaweed diversity based on secondary data and reported 844 species of seaweeds with 434, 194, and 216 species of red, brown, and green seaweeds, respectively. The CSMCRI team explored the seaweed diversity of the Gujarat and Tamil Nadu coasts (Jha et al. 2009) known for their relative abundance of seaweeds. These two maritime states, collectively, are home to 366 seaweed species that account for nearly half of India's total seaweed diversity.

\section{Seaweed diversity of Gujarat coast}

The Gujarat coast, more than $1600 \mathrm{~km}$ long, is located in northwest India. The coastline has varied topography, geomorphology, coastal processes and river discharges into the Arabian Sea and has been broadly segmented into five regions viz. the Rann of Kachchh, the Saurashtra coast, Gulf of Kachchh, Gulf of Khambhat and the South Gujarat coast (Figure 2). Among these regions, the Gulf of Kachchh, extending over $1000 \mathrm{~km}$, is a wealthy coastline with the Marine National Park and Marine Sanctuary that includes 42 islands, rocky intertidal regions and mangrove forests supporting rich seaweed diversity. The Gulf of Khambhat is a delta region with several major rivers flowing into the sea, including the Narmada, Tapti and Mahi Sabarmati rivers. The intertidal region comprises mud and sand flats with minimal seaweed diversity.

The survey documenting the intertidal seaweed diversity of the Gujarat coast revealed 198 species representing all three major groups of seaweed; Rhodophyta 109 species from 62 genera; Chlorophyta 54 species from 23 genera; Phaeophyceae 35 species from 16 genera. Seaweed diversity is rich in the Gulf of Kachchh islands totaling 130 species from Dani, Dhabdhaba, Kalubhar, Manmarodi, and Narara Islands. Species collected ranged from 93 species from Kalubhar Island to a minimum

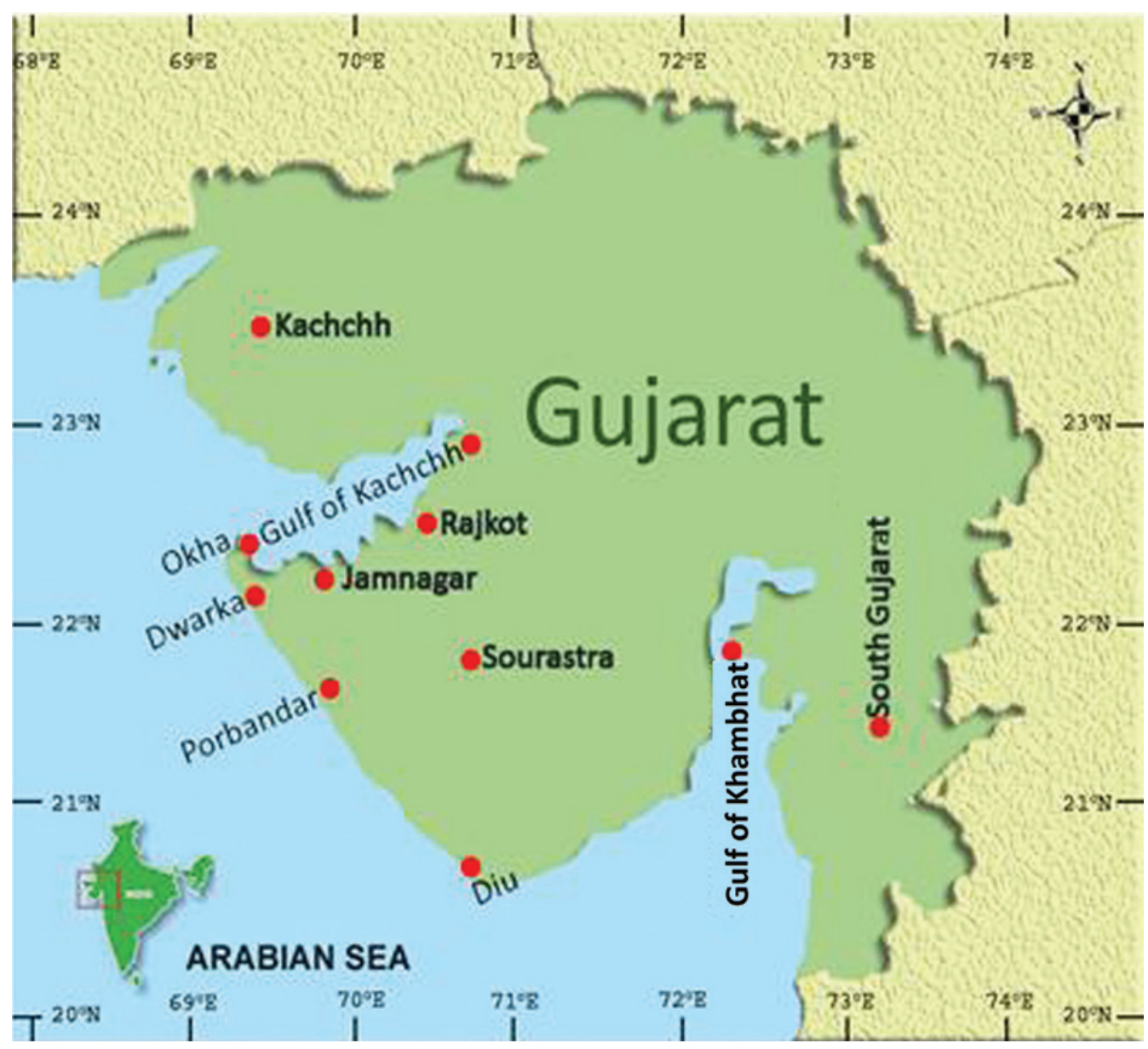

Figure 2: Map of Gujarat coast. 
number of 14 species collected from Narara Island (Jha et al. 2009).

\section{Seaweed diversity of Tamil Nadu coast}

The Southeast Indian State of Tamil Nadu's coastline (Figure 3) is $1076 \mathrm{~km}$ long with 13 coastal districts and 15 major ports and harbours. The convergence of the Bay of Bengal, Arabian Sea, and the Indian Ocean at India's southern tip is the unique feature of this coast. Distinct variations are seen in the nature of substratum in the intertidal and subtidal regions. The northern coastal area has long and wide sandy beaches intermittently populated with flat rocks, boulders and stones in the lower and upper intertidal regions, experiencing severe surf energy. Species belonging to the genera Ulva, Chaetomorpha, Bryopsis and Grateloupia inhabit the rocks and boulders. The central Tamil Nadu coast includes Palk Bay, which falls within the Cauvery deltaic region. The region's muddy intertidal and subtidal coast is due to the confluence of many rivers flowing to the sea. Several species of

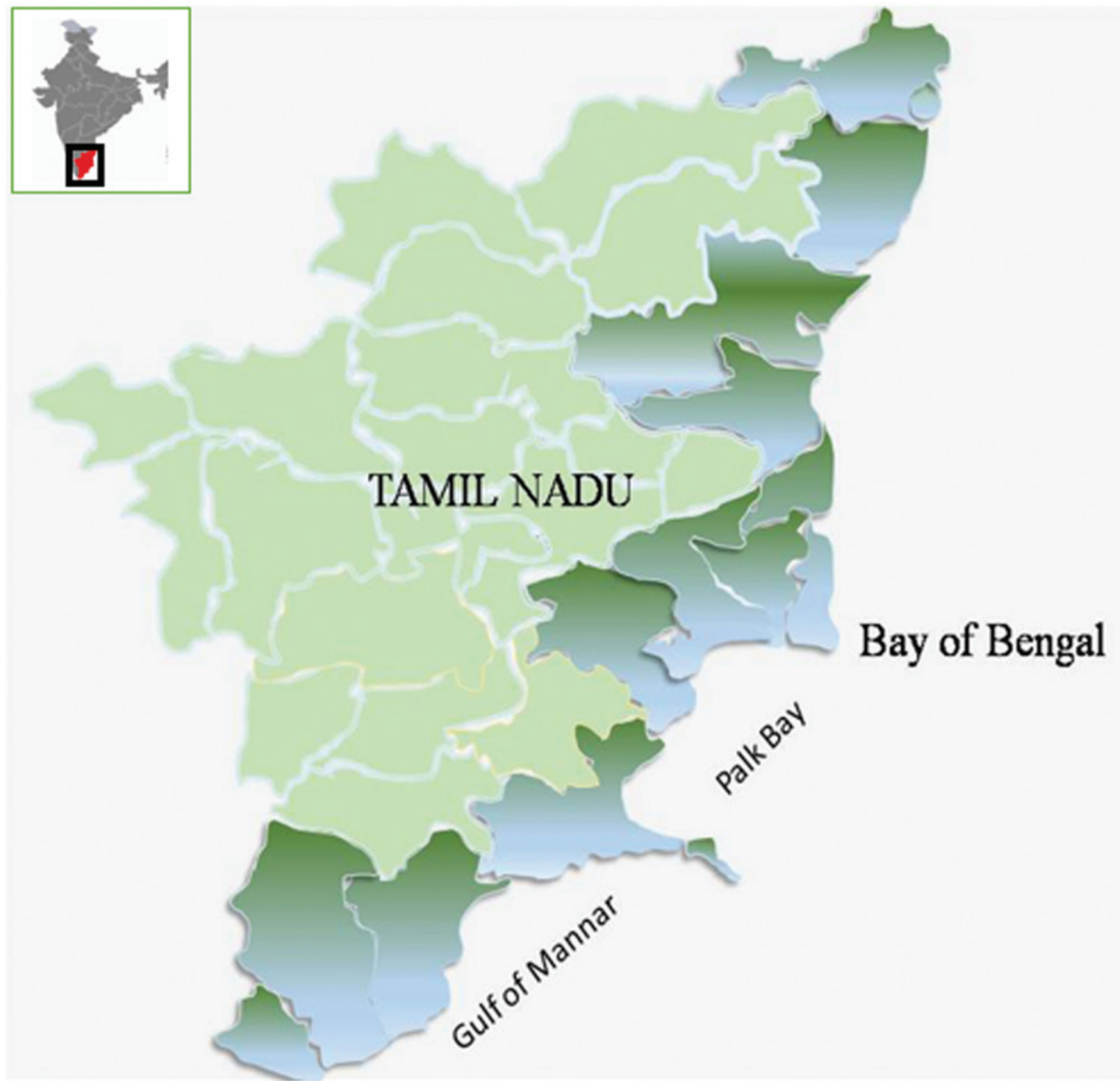

Figure 3: Map of Tamil Nadu coast. 
Gracilaria, including G. edulis, G. foliifera, G. verrucosa and G. salicornia are dominant and commercially harvested in this region. The Gulf of Mannar, located in the southern part of Tamil Nadu, has a rich diversity from all three seaweed groups. Intertidal and subtidal rocks extend up to $1 \mathrm{~m}$ deep and they support abundant growth of Sargassum, Acanthophora and Hypnea species. The subtidal coral reefs are populated with Gelidiella, Turbinaria and Sargassum species. The southern Gulf of Mannar's rocky intertidal and lower intertidal regions maintain rich populations of several Ulva species. Ulva has been collected from all 20 Gulf of Mannar islands supporting high seaweed diversity with potential economic importance.

Studies carried out to determine seaweed diversity from 42 Indian coastal stations and 14 Gulf of Mannar islands (Figure 3) showed a total of 282 seaweed species (Anon 2012). Among these, 80 species were Chlorophyta, 56 species were Phaeophyceae and 146 species were Rhodophyta. The genus Caulerpa was represented by the highest number of species (24) among the green algae, followed by Codium with seven species and Halimeda and Ulva with six species each. The genera Acrosiphonia, Anastomonas, Boergesenia, Dictyosphaeria, Neomreis, Microdictyon, Struvea, Valonia and Valoniopsis have a single species each. In brown algae, the genus Sargassum had the greatest number of species (15) followed by Dictyota with 10 species and Padina with seven species. The genera Turbinaria, Dictyopteris and Chnoospora had three species each and the genera Ectocarpus, Hormophysa, Hydroclathrus, Iyengaria, Rosenvingea and Zonaria were each represented by a single species. Among the red algae, the genus Gracilaria represented the highest number of species (20) while the genus Laurencia had 12 species. Other red algal genera found include seven species of Hypnea, six species of Grateloupia and several genera that were represented by a single species including: Asparagopsis, Bostrichia, Botryocladia, Chondrococcus, Chondrocanthus, Dasya, Dictyurus, Digenea, Enantiocladia, Griffithesia, Halichrysis, Helminthocladia, Neurymenia, Nitophyllum, Peyssonnelia, Tenaciphyllum and Wrangelia (Anon 2012).

\section{Commercial harvests of seaweeds along the Southeast Indian coast}

According to FAO (2014), global seaweed harvests from wild stocks ranged between 1.0 and 1.3 million tonnes from 2000 to 2009. Unlike Southeast Asian countries, Indian seaweed industries rely heavily on wild harvests for phycocolloid production. Gelidiella acerosa (Forsskal) and Feldmann \& Hamel and Gracilaria edulis (S.G. Gmelin) P.C.
Silva are harvested for agar production, while Sargassum spp. and Turbinaria spp. are the source material for alginate production. The Gulf of Mannar and Palk Bay coasts are highly productive regions for commercial collection of agarophytes and alginophytes. A long and wide coral reef (140 km length), running along the southern side of the 20 islands of the Gulf of Mannar, supports luxuriant growth of seaweeds; especially Sargassum spp., Turbinaria spp. and G. acerosa. Similarly, the shallow and silty Palk Bay coast harbours rich growth of Gracilaria salicornia (C. Agardh) and G. edulis. Harvesting techniques include: cutting erect fronds from mono-specific patches of the targeted seaweed. Harvesting takes approximately 12 days per month during spring tides. In the Gulf of Mannar, 1555 fisherfolk from 14 coastal villages are known to harvest seaweeds, including 1270 women and 285 men. Along the Palk Bay coast, 670 fisherfolk from 24 villages harvest seaweeds. Among them, 460 are women and 210 are men. In India, seaweed gathering is traditionally considered as a job for women and teenagers. They earn an average annual income of US $\$ 1000$. Seaweed harvesting is seasonal work and helps people earn additional income for their families. Once the seaweed collection season ends, fisherfolk shift their efforts towards fishing and allied jobs.

Harvested seaweeds are dried on the shore and sold to industry buyers. Gelidiella acerosa value is USD $\$ 1800$ per dry tonne; Gracilaria spp, Sargassum and Turbinaria value is approximately US $\$ 800$ per dry tonne. The harvested seaweeds are used for production of phycocolloids, including agar and alginates by 33 industrial firms.

Harvesting of Gelidiella acerosa and Gracilaria edulis from 2005 to 2016 resulted in a gradual depletion of natural resources due to over exploitation (Figure 4), whereas

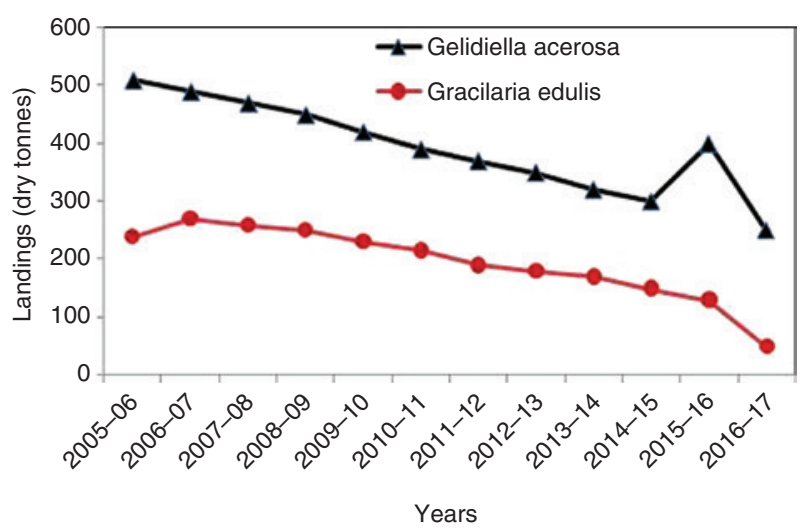

Figure 4: Annual landings of agarophytes from wild harvest. Courtesy of $($ ) Madurai Agar Manufacturer Welfare Association, Madurai. Gelidiella acerosa and Gracilaria edulis are collected from Gulf of Mannar islands and mainland coast from Kilakkarai to Valinokkam of Southeast Indian coast. 


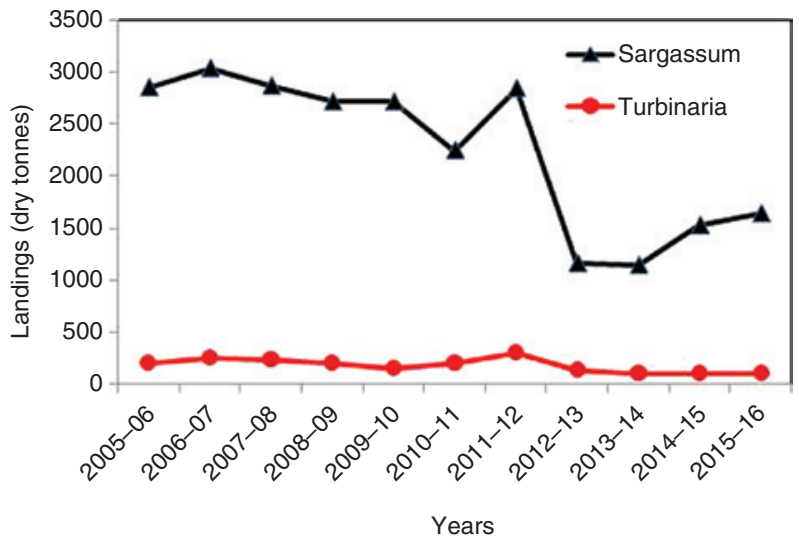

Figure 5: Annual landings of alginophytes from wild harvest. Courtesy of $\odot$ SNAP Natural Products and Alginates (P) Ltd., Ranipet. Sargassum wightii, Turbinaria conoides, T. ornata and T. decurrens are collected from Gulf of Mannar islands and mainland coast from Rameswaram to Kanyakumari of Southeast Indian coast.

Sargassum spp. and Turbinaria spp. landings exhibited an irregular value trend (Figure 5). Over-harvesting of seaweeds has a direct effect on marine biodiversity, particularly on the abundance of motile invertebrates, fish and other animals occupying higher trophic levels (Migné et al. 2014, Phillippi et al. 2014). Over-harvesting can negatively impact recruitment and reduce contributions to the marine carbon cycle (Levitt et al. 2002). Intertidal and subtidal seaweeds dominate the habitat and exert a strong influence on the community recruitment (Thompson et al. 2010).

\section{Phycocolloid production}

\section{Agar}

Indian agar production started in 1940 on a cottage-industry scale, with Gracilaria edulis utilized as the raw material. Later, a process for industrial manufacture of agar was developed using Gelidium micropterum Kutzing as the raw material. With the development of these industrial methods, a few processors started agar production using either Gelidiella acerosa or G. edulis as raw material. Since plentiful wild stock resources of $G$. acerosa and G. edulis were available, several processors flourished during the 1960s and 1970s. Presently, 25 agar processors are operating with average agar production of 300 and 400 tonnes per annum (Figure 6). Food-grade agar represents $67 \%$ of the total annual Indian agar production. Agar production increased steadily, reaching maximum production in 20142015. Landings of G. edulis decreased substantially during the same time frame corresponding to increased raw

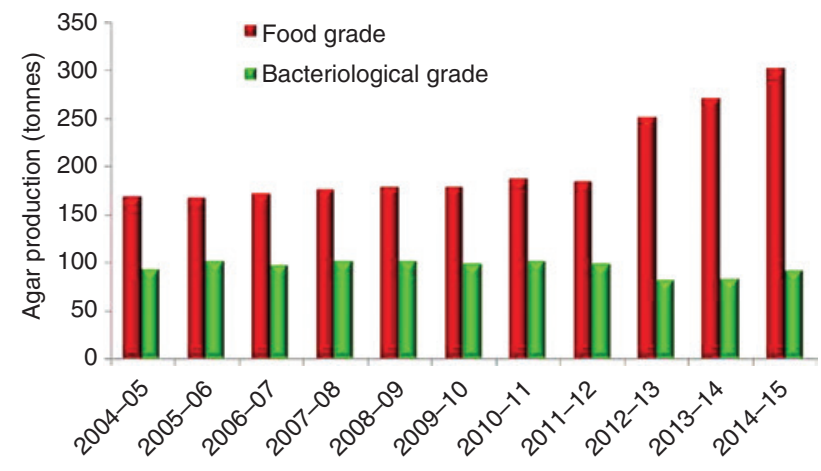

Figure 6: Agar production in India. Courtesy of () Madurai Agar Manufacturer welfare association, Madurai.

material demands by the processing industry. As a result of supply shortages, several agar processors imported G. edulis from Sri Lanka and Indonesia. Additionally, an average of 400 dry tonnes per annum of Gracilaria salicornia were harvested from Palk Bay wild stocks from 2012 to 2015 (Mr. Bose, President, Madurai Agar Association, personal communication). Gracilaria salicornia is a source of foodgrade agar with a gel strength of approximately $510 \mathrm{~g} \cdot \mathrm{cm}^{-2}$ (Meena et al. 2008). This food-grade agar meets most domestic Indian requirements. Food grade agar powder fetches higher prices than agar strips.

Bacteriological grade agar production in India decreased sharply after 2011-2012, with the lowest production of 80 tonnes during 2012-2013 (Figure 6). M/s Marine Chemicals, Cochin a major agar producer, produces more than $70 \%$ of the bacteriological-grade agar produced in India. The company imports all its agar raw material from outside India and buys crude agar from small-scale processors in India and refines it for export to other countries.

\section{Alginate}

Alginate is extracted from Sargassum spp. and Turbinaria spp. harvested from wild stocks along the Gulf of Mannar coast. Alginate production has steadily increased from 98 metric tonnes in 2003-200 metric tonnes in 2016 (Figure 7). SNAP Natural Products and Alginate (P) Ltd. is the major producer. SNAP produces a variety of alginate products, including food, pharmacological, industrial, textile and welding grades. Alginates have been used in a wide range of applications as thickening and gelling agents in the food and feed processing industries. Pharmaceutical industrial concerns utilize alginate coloring agent as stabilizers and in the textile industry as water proofing, paper coating and in wastewater treatment. 


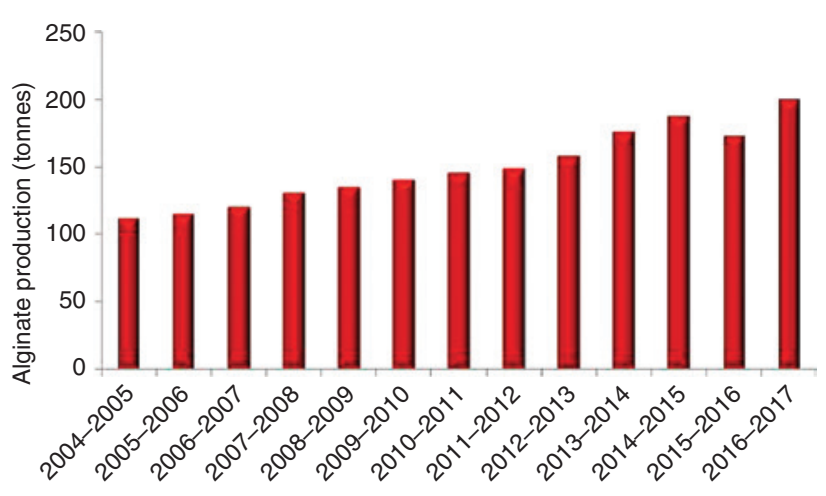

Figure 7: Alginate production in India. Courtesy of $\odot$ SNAP Natural Products and Alginates (P) Ltd., Ranipet.

\section{Seaweed culture}

The Southeast Indian coast is considered to be most suitable for commercial seaweed cultivation because it has shallow, wide and flat coastal shorelines with moderate wave action, and rich in nutrients including phosphorus and nitrogen. Seawater salinities and temperatures are optimal for seaweed production making the region suitable for commercial seaweed cultivation year round, except during the monsoon season. Essential cultivation supplies including bamboo, rope and anchors are readily available at reasonable prices close to the cultivation sites. Above all, willing contingents of 14-35 year-old age group fisher women are available for seaweed cultivation (Ganesan et al. 2017).

\section{Culture of carrageenophytes}

\section{Kappaphycus alvarezii}

Kappaphycus alvarezii is one of the most widely traded tropical red seaweeds, utilized as a source for the extraction of the commercially important phycocolloid kappacarrageenan ( $\kappa$-carrageenan). Due to its unique gelling properties, kappa-carrageenan is used as an emulsifier, binder, thickener and gelling agent in a diverse range of products including toothpaste, cosmetics, ice cream, pet foods, beverages, pharmaceuticals, personal care and dairy products.

Farming of Kappaphycus alvarezii in India originated with a few grams of biomass imported from Japan by CSIR-CSMCRI in the early 1990s; the importation followed the quarantine procedures appropriate for cultivation and utilization. Initial out-planting trials were done along the Northwest's Okha coast following laboratory acclimatization studies. Subsequently, southeast Tamil Nadu's Mandapam coast was explored for its suitability as a potential cultivation region from 1995 to 1997. Initial field trials evaluated a variety of cultivation methods, including (a) polythene bags, (b) fish net bags and (c) net enclosed open culture (Eswaran et al. 2002). Eventually, the bamboo raft method was adopted. In this method, $3 \times 3 \mathrm{~m}$ rafts made with $7-8 \mathrm{~cm}$ diameter bamboo were reinforced utilizing diagonally orientated bamboo braces approximately $1.3 \mathrm{~m}$ long to maintain integrity in open sea conditions. Lower portions of the rafts were covered with fishing net minimizing grazing and biomass drifting. Twenty plantings (fresh cuttings) of approximately $100 \mathrm{~g}$. each were attached to raft ropes ( $3 \mathrm{~mm}$ thick polypropylene) at regular intervals using a braider. The seeded ropes were tied at both ends of the bamboo rafts at $15-\mathrm{cm}$ intervals. Initial seeding weight of each raft averaged $40 \mathrm{~kg}$ fresh wt. and rafts were moored in clusters of 5-10 and anchored to 30-kg mooring stones. Deployed seaweed cuttings began growing immediately and were harvested after a growth period of approximately 45 days (Figure 8A,B; Mantri et al. 2017).

Kappaphycus alvarezii commercial cultivation was initiated in 2001 along the southeast coast of Tamil Nadu by Pepsico India Holdings (P) Ltd., Gurgaon, India after licensing cultivation technology from CSIR-CSMCRI, Bhavnagar. The company successfully adopted a contractfarming model with buy-back arrangements for seaweed produced by the women's Self-help Groups (SHGs). Infrastructure was provided to the SHGs through the national bank subsidies. The contract farming model allocated 45 rafts to each SHG individual member. The amount of distributed rafts was tied to the planting and harvesting 45-day scheduled farming period. Each farmer could conveniently plant and harvest one raft per day. Harvests averaged $240 \mathrm{~kg}$ of live seaweed per raft with approximately $40 \mathrm{~kg}$ used as raft seeding material for the subsequent farming cycle, leaving $200 \mathrm{~kg}$ of fresh biomass or $20 \mathrm{~kg}$ of dry seaweed available for sale. More than 1500 households along the Tamil Nadu coast engaged in seaweed farming as an alternative livelihood, each earning approximately US \$300 per month (Table 1).

Seaweed cultivation has emerged as viable option for the economic improvement of low income coastal communities in India (Krishnan and Narayanakumar 2010, Periyasami et al. 2014, 2015, Mantri et al. 2017). Production increased significantly from 21 dry metric tonnes in 2001-1490 dry tonnes in 2013, totaling 7187 dry tonnes biomass, worth US \$2.5 million during the 13-year cultivation period (Mantri et al. 2017). Kappaphycus alvarezii commercial farming from Tamil Nadu experienced a 

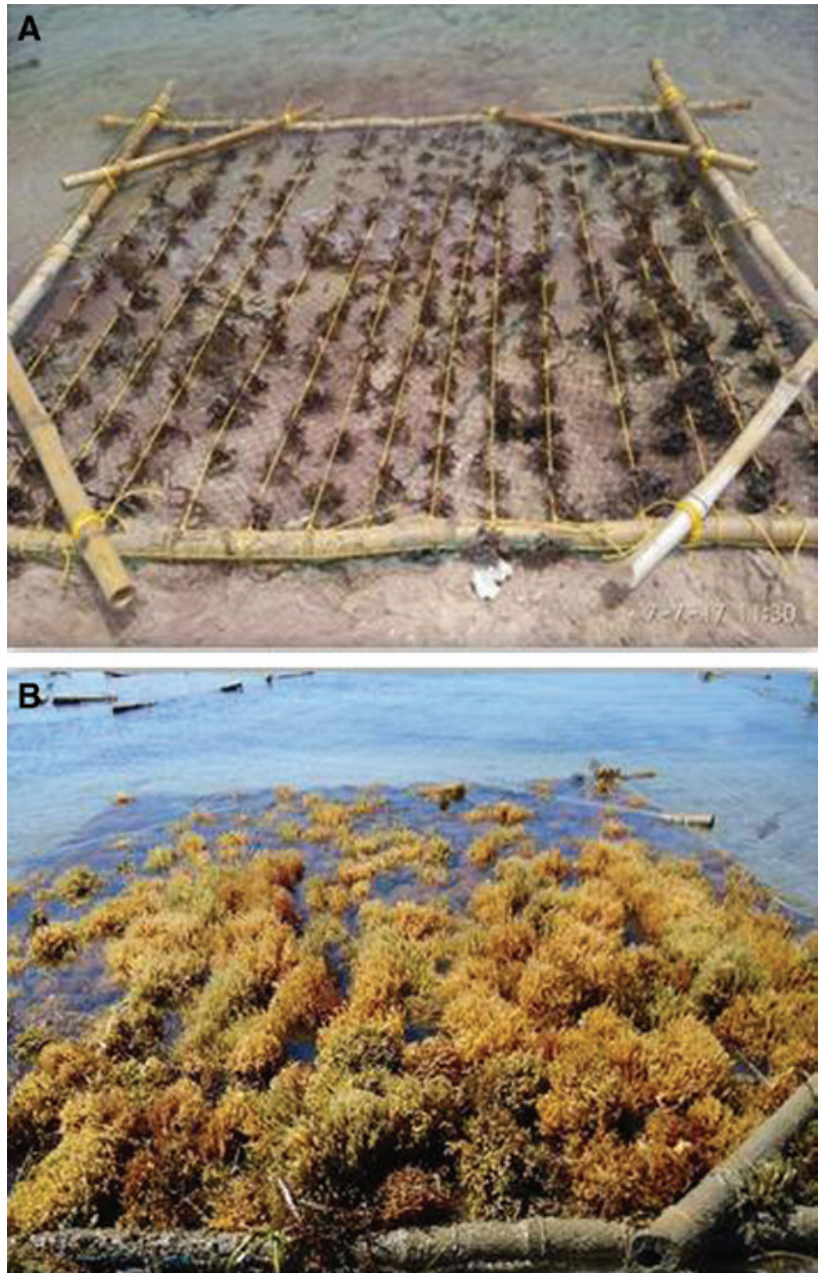

Figure 8: Kappaphycus alvarezii cultivation.

(A) Raft seeded with K. alvarzii; (B) K. alvarezii grown on raft.

significant decline in 2013 correlated with a sudden rise in seawater temperature to $36^{\circ} \mathrm{C}$ and a subsequent onset of bacterial disease. Crop production yields slowly recovered starting in 2016 and increased production is anticipated in the next couple of years. Kappaphycus alvarezii commercial production has expanded to six coastal districts in
Tamil Nadu and expansion is underway in Gujarat, where commercial activities commenced in 2017.

\section{Hypnea musciformis}

Hypnea musciformis (Wulfen) J.V. Lamouroux is an indigenous carrageenophyte yielding kappa-carrageenan. Hypnea musciformis is found in natural beds along the shorelines of several Gulf of Mannar islands. Lagoon waters of Krusadai Island were selected for pilot-scale cultivation of $\mathrm{H}$. musciformis utilizing the monoline method (Figure 9; Ganesan et al. 2006). Young actively growing apical portions of $H$. musciformis ranging from 2 to $2.5 \mathrm{~g}$ fresh wt. and $5 \mathrm{~cm}$ long, were inserted between the braids of 20-m long coir ropes made from coconut husks. The ropes were anchored to wooden stakes and kept afloat with plastic floats. A total of $2000 \mathrm{~m}$ of coir ropes were seeded and placed in 10 plots, each consisting of 10 ropes, each $20 \mathrm{~m}$ long. Hypnea was harvested at 25-day intervals reaching 30-35 cm lengths. Thalli were clipped leaving fragments to grow further. Harvests ranged from 250 to $300 \mathrm{~g}$ fresh wt $\mathrm{m}^{-1}$ rope (Ganesan et al. 2006). Fifteen harvests per year yielded a total biomass of 38-40 tonnes fresh wt ha-1 year-1 $^{-1}$ Ganesan et al. 2006).

\section{Sarconema filiforme}

Sarconema filiforme (Sonder) Kylin is a carrageenophyte containing hybrids of $\alpha$-carrageenan, iota-carrageenan and pyruvated $\alpha$-carrageenan (Ganesan et al. 2015a). Currently, industrial utilization of hybrid carrageenans, especially in the food and cosmetic industries, is significantly increasing. Indian waters have two species of Sarconema viz. S. scinaioides and S. filiforme; of these two species, S. scinaioides inhabits the intertidal region of India's north west coast (Jha et al. 2009), while S. filiforme is sparsely distributed along the southeast and northwest

Table 1: Economics analysis of seaweed cultivation.

\begin{tabular}{|c|c|c|c|c|c|}
\hline S. no. & Expenditure details & $\begin{array}{r}\text { Kappaphycus } \\
\text { alvarezii }\end{array}$ & $\begin{array}{r}\text { Gracilaria } \\
\text { edulis }\end{array}$ & $\begin{array}{r}\text { Gelidiella } \\
\text { acerosa }\end{array}$ & $\begin{array}{r}\text { Gracilaria } \\
\text { dura }\end{array}$ \\
\hline 1 & $\begin{array}{l}\text { Infrastructure cost, farmers contribution } \\
\text { with } 50 \% \text { subsidy (in Rs.) }\end{array}$ & 250,000 & 300,000 & 300,000 & 300,000 \\
\hline 3 & No. of beneficiaries ha-1 & 5 & 5 & 5 & \\
\hline 3 & Biomass produced raft ${ }^{-1}(\mathrm{~kg}$ dry $\cdot \mathrm{wt})$ & 10 & 2.5 & 3.0 & 2.0 \\
\hline 4 & Cost of dry weed kg-1 (Rs.) & 40 & 45.00 & 120.00 & 100 \\
\hline 5 & No. of cycle year-1 & 07 & 07 & 03 & 05 \\
\hline 4 & Value of biomass produced (Rs.) & $1,400,000$ & 787,500 & $1,080,000$ & $1,000,000$ \\
\hline 5 & Net profit person ${ }^{-1}$ month $^{-1}$ (Rs.) & 19,166 & 8125 & 13,000 & 11,660 \\
\hline
\end{tabular}



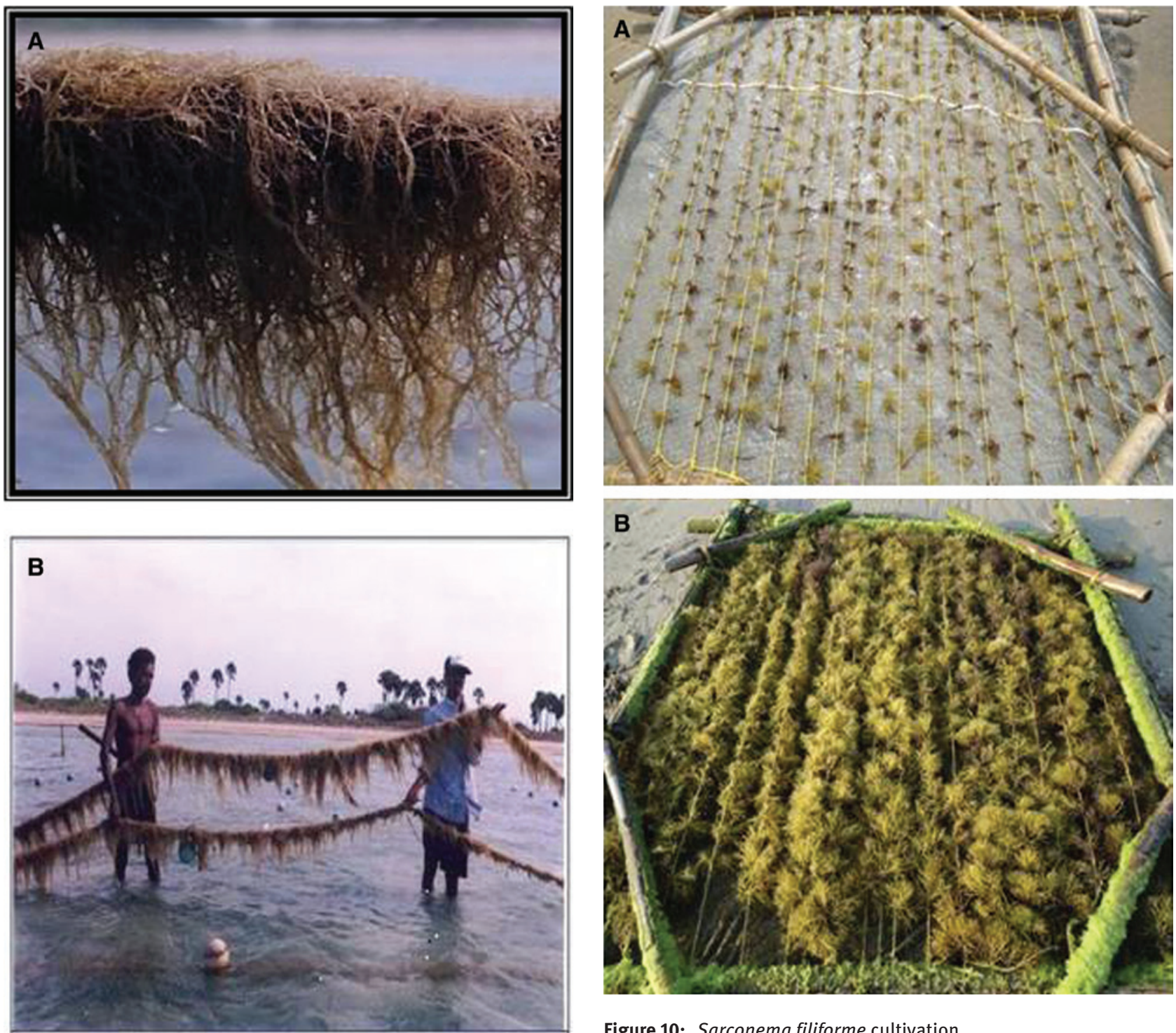

Figure 10: Sarconema filiforme cultivation.

Figure 9: Monoline method of cultivating Hypnea musciformis. (A) Well grown $H$. musciformis on coir rope; (B) a pilot scale farm of H. musciformis with 2000-m long coir rope.

coasts (Oza and Zaidi 2001). Pilot-scale cultivation of S. filiforme was completed along the Mandapam coast, utilizing the bamboo raft method. Young and actively growing S. filiforme (average $0.8 \pm 0.25 \mathrm{~g}$ fresh wt) were attached to the ropes at $5-\mathrm{cm}$ intervals. Attached to each rope were 25 algal cuttings totaling $20 \mathrm{~g}$. fresh wt rope ${ }^{-1}$. Each raft, with 20 ropes, totaled $400 \mathrm{~g}$ fresh wt equivalent to $160 \mathrm{~g}$ fresh wt $\mathrm{m}^{-2}$ (Ganesan et al. 2015a).

Sarconema reached harvestable size in 25 days and all plants were completely harvested and ropes were freshly stocked with new cuttings after every harvest (Figure 10). 100 rafts were planted with $S$. filiforme and seven harvests were completed each year for 3 consecutive years from

(A) Seeded lines with fish net; (B) S. filiforme ready for harvest.

2011 to 2013. An average of $2.3 \mathrm{~kg}$ fresh $\mathrm{wt} \mathrm{m}^{-2}$ was harvested from the initial inocula of $160 \mathrm{~g}$ fresh $\mathrm{wt} \mathrm{m}^{-2}$. An average of 150 fresh tonnes ha ${ }^{-1}$ year $^{-1}$ of $S$. filiforme could be obtained utilizing this method (Ganesan et al. 2015a).

\section{Culture of agarophytes}

\section{Gelidiella acerosa}

Gelidiella acerosa is the preferred source of raw material for the production of Indian pharmaceutical and bacteriological grade agar with a gel strength ranging from 850 to $2200 \mathrm{~g} \mathrm{~cm}^{2}$ (Ganesan et al. 2015b). Indian agar processors 
produce an average of 100 tonnes of pharmacological grade agar from $G$. acerosa. Unscrupulous harvesting of natural seaweed beds continuously led to gradual reduction of wild standing stocks. The over exploitation of natural Gelidiella populations necessitated the development of cultivation methods for farming seaweeds. Initial methods included long-line ropes (Subbaramaiah et al. 1975), single rope floating technique (SRFT; Subbaramaiah and Banumathi 1992), coral stone culture method (Patel et al. 1986), and concrete stone method (Ganesan et al. 2009). These methods resulted in low biomass yields and were difficult to manage in terms of planting, monitoring and harvest practices. Therefore, it became necessary to develop improved methods resulting in higher biomass and easier cultivation operations. The bamboo raft method successfully used for the commercial
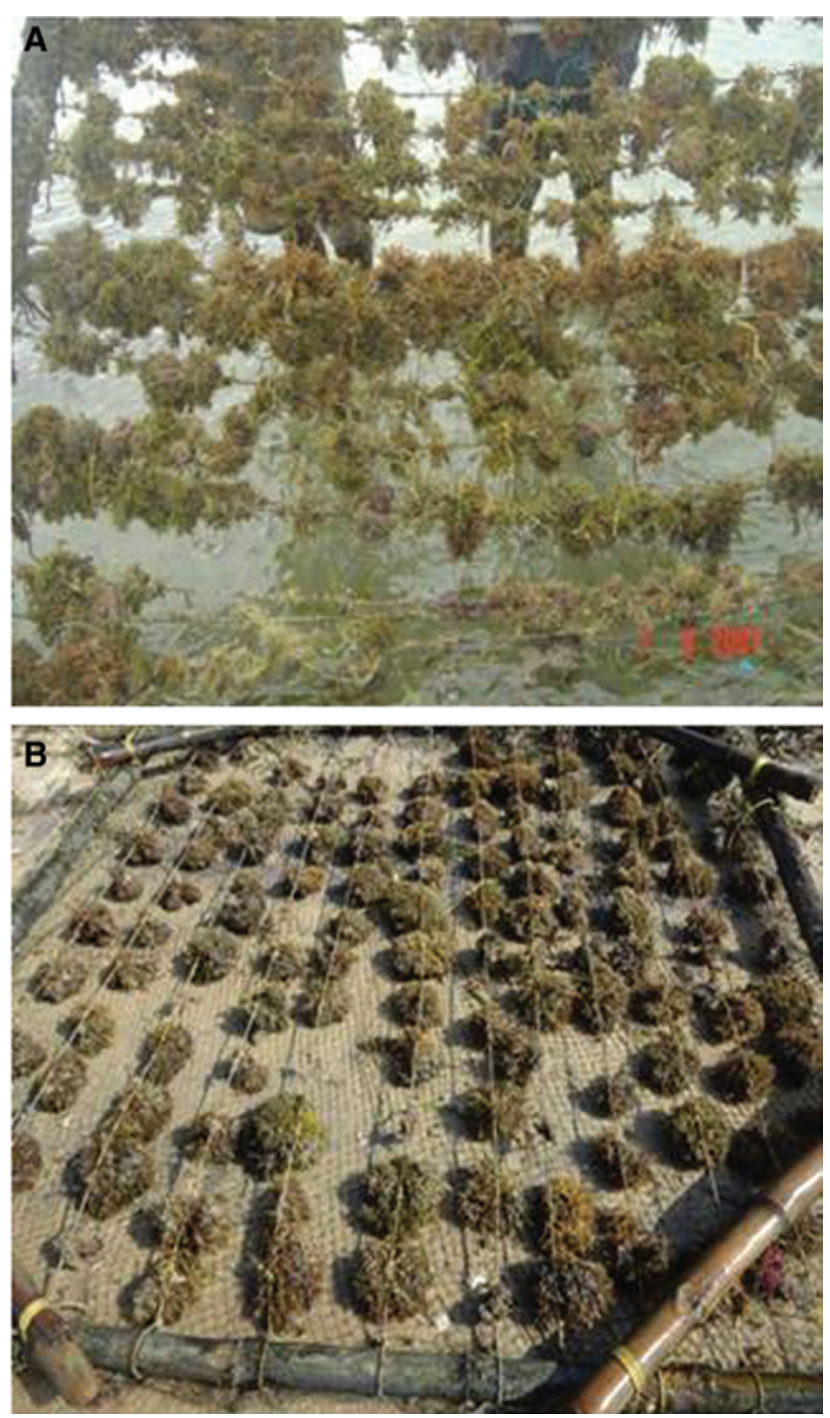

Figure 11: Gelidiella acerosa cultivation.

(A) Raft method; (B) suspended stone method. cultivation of Kappaphycus alvarezii was adopted for $G$. acerosa (Figure 11A; Ganesan et al. 2009) yielding significantly higher harvested biomass than previous methods. The suspended stone method was developed to enhance the bamboo raft method by tying approximately $2 \mathrm{~g}$ of seedlings to nylon thread, which was wound around the stones (15-70 $\mathrm{cm}^{2}$ area and 100-200 g weight) and hung $5 \mathrm{~cm}$ below the polypropylene ropes ( $3 \mathrm{~mm}$ diam). The polypropylene ropes were tied across the bamboo frames of $1.5 \times 1.5 \mathrm{~m}$ size. The suspended ropes orientated the algal thalli upwards. Eight inoculated stones were tied to each rope with 10 polypropylene ropes per square raft $(2.0 \times 2.0 \mathrm{~m})$. Each raft was seeded with $160 \mathrm{~g}$ fresh biomass equivalent to $71 \mathrm{~g}$ fresh wt $\mathrm{m}^{-2}$. Harvesting entailed cutting erect thalli and leaving the basal portions on the stones for further growth (Figure 11B). The stone-modified raft method resulted in three harvests per year yielding 8-15 $\mathrm{kg}$ fresh wt raft ${ }^{-1}$ per harvest (Ganesan et al. 2011).

\section{Gracilaria edulis}

Gracilaria edulis, the major raw material source for Indian food-grade agar, exhibits a gel strength of approximately $490 \mathrm{~g} \mathrm{~cm}^{-2}$ with $8 \%$ alkali treatment (Meena et al. 2008). Although the Indian coastline has 32 species of Gracilaria (Krishnamurthy 1971), G. edulis is the dominant alga with significant standing stocks. Indian agar industries annually harvest 100-200 dry tonnes of $G$. edulis from wild stocks along the southeast coast of India. Over-harvesting of this resource has led to depletion of wild stocks. Several technologies have been developed for G. edulis cultivation. The long-line rope method yielded approximately 20 tonnes dry wt ha ${ }^{-1} \mathrm{y}^{-1}$ (Raju and Thomas 1971) and increased to 30 tonnes dry wt ha ${ }^{-1} \mathrm{y}^{-1}$ with the adoption of the Single Raft Floating Technique (Subbaramaiah and Thomas 1995). Both methods experienced significant grazing pressure hindering their commercial scale adoption. Finally, the bamboo raft method was adopted for $G$. edulis cultivation as this method minimized seaweed drifting and herbivore grazing by covering the lower portion of bamboo raft below the planted ropes with fishing net.

In the bamboo raft method, young fragments of Gracilaria edulis (average $2.0 \pm 0.25 \mathrm{~g}$ fresh wt) were tied to polypropylene ropes at $5-\mathrm{cm}$ intervals. Each rope contained 25 seedlings with a total fresh weight of $50 \mathrm{~g} \mathrm{rope}^{-1}$. A bamboo raft $(2 \times 2 \mathrm{~m}$ size $)$ with 20 ropes had an initial seedling biomass of $1.0 \mathrm{~kg}$ fresh wt raft ${ }^{-1}$ (Figure 12A). Seven harvests were completed in a year (Figure 12B) and 35 tonnes dry wt ha-1 $\mathrm{y}^{-1}$ were harvested (Ganesan et al. 2011). 

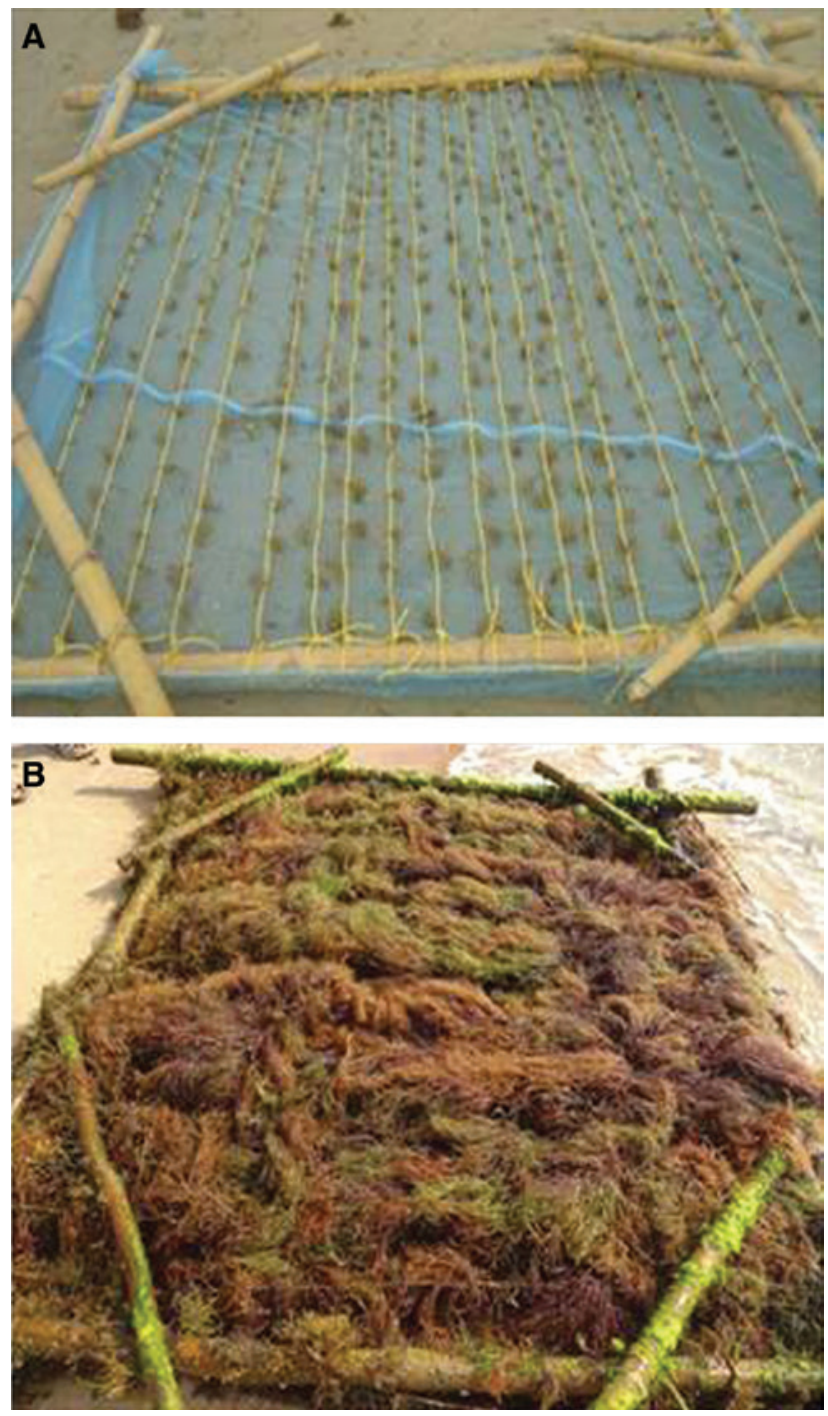

Figure 12: Gracilaria edulis cultivation.

(A) Young seedlings on raft; (B) dense growth of $G$. edulis after 45 days.

\section{Gracilaria dura}

Gracilaria dura (C. Agardh) J. Agardh attracts significant interest as a source of agarose with a gel strength of 2200 $\mathrm{g} \mathrm{cm}^{-2}$, gelling temperature of $30^{\circ} \mathrm{C}$ and sulfate content of $0.15 \%$ (Prasad et al. 2007). The distribution of G. dura is restricted to the west coast of India. Several experimental scale cultivation methods were initiated along India's southeast coast including the bottom net, net bag, net pouch and bamboo raft methods (Veeragurunathan et al. 2015). Ultimately, the bamboo raft method resulted in the largest yield. Bamboo rafts $(2 \times 2 \mathrm{~m}$ size $)$, with initial plant density of $1.2 \mathrm{~kg}_{\text {fresh }} \mathrm{wt} \mathrm{raft}^{-1}$, yielded $8 \mathrm{~kg}$ fresh wt raft $^{-1}$ in 45- to 60-day cultivation cycles. Six harvests were achieved in a year (Figure 13A).
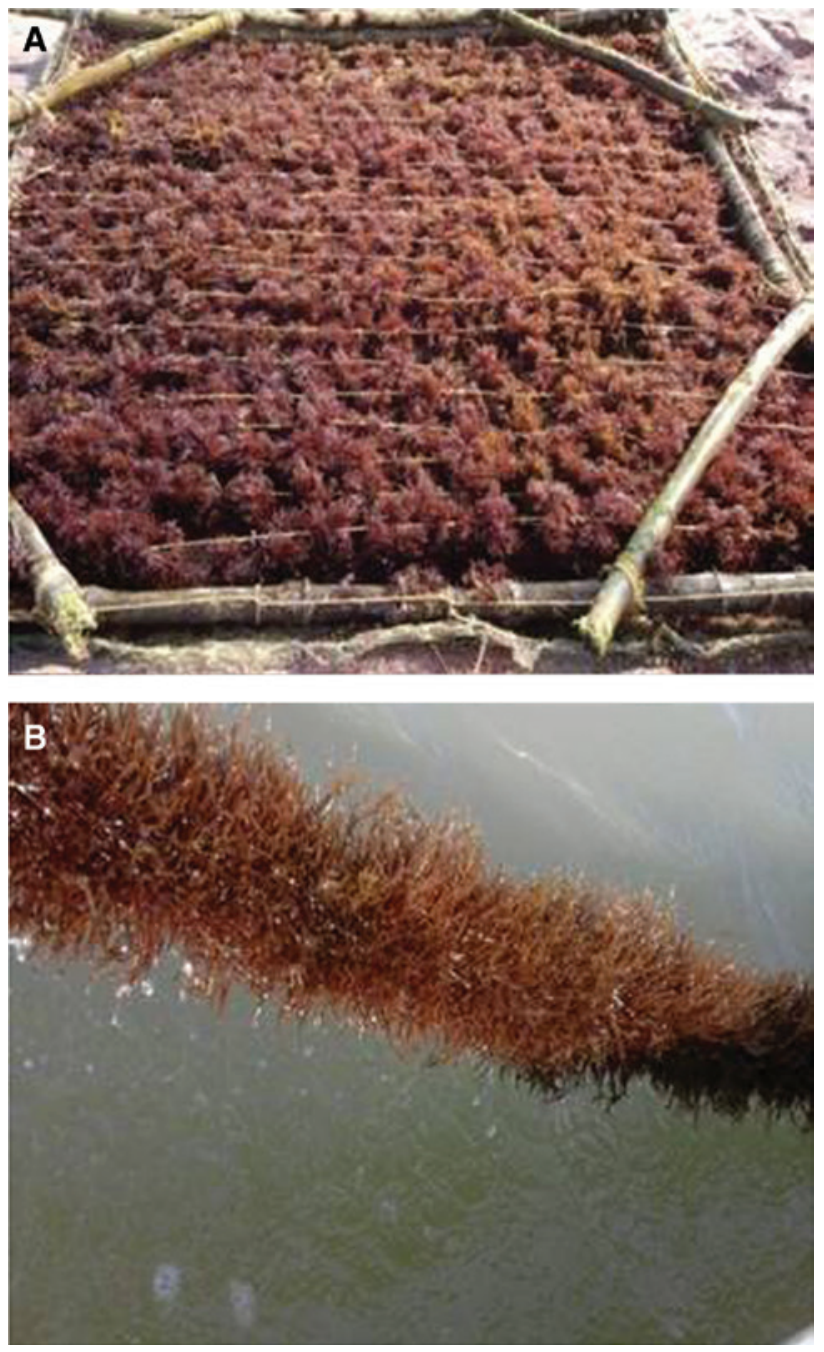

Figure 13: Gracilaria dura cultivation. (A) Raft method; (B) tube net method.

Recently, an initial cultivation effort for G. dura along the Simar, Gujarat coast, in northwest of India has utilized the tube-net method. The tube-net method's seed material (10 kg fresh) was uniformly loaded in $25-\mathrm{m}$ tube nets made from fishing nets and sealed at both ends with polypropylene rope (Figure 13B), then transplanted in rows to the shallow coastal waters with anchor supports and floats. The daily average growth of $G$. dura ranged from 2 to $3 \%$ day $^{-1}$ and the yield was $30-35 \mathrm{~kg}$ fresh biomass in 40-45 days (Mantri, personal communication).

\section{Gracilaria salicornia}

Recently, Gracilaria salicornia has been commercially harvested from wild stocks as a result of the decline of 

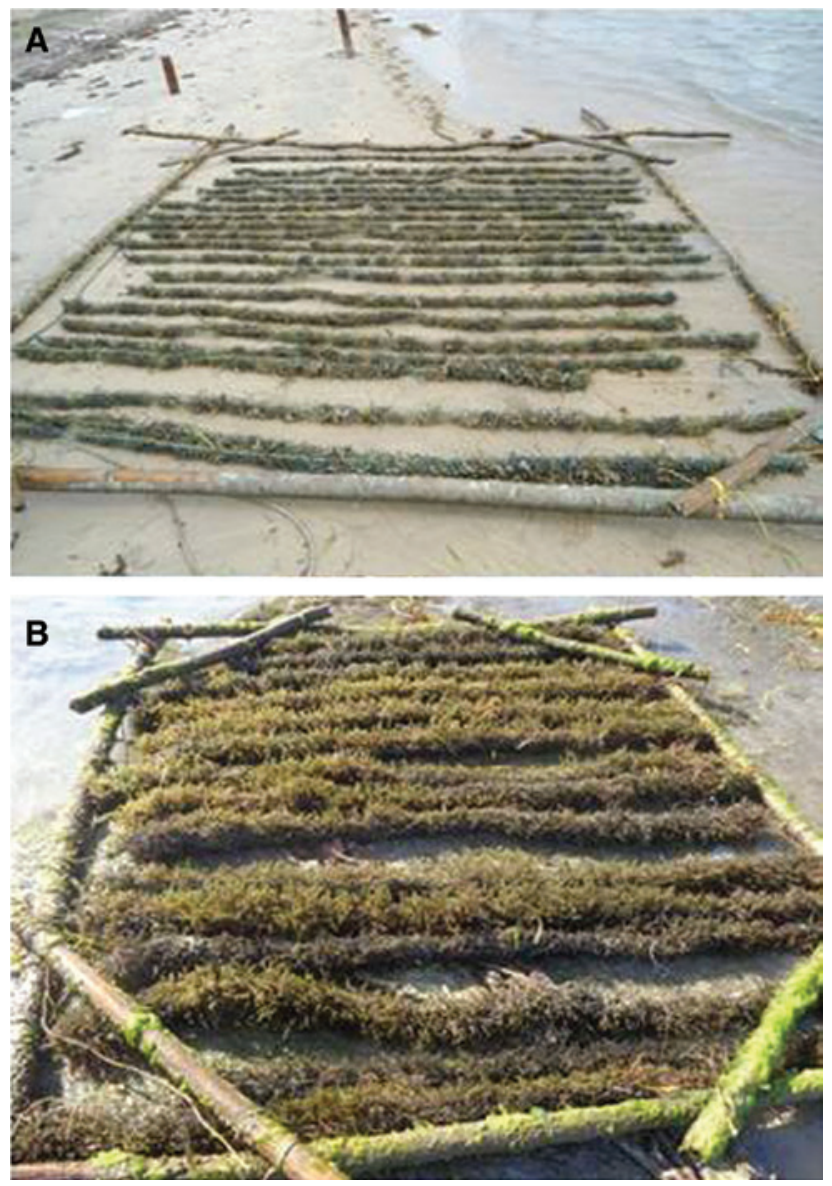

Figure 14: Tube net method of cultivating Gracilaria salicornia. (A) At seeded stage; (B) at harvest stage.

Gracilaria edulis standing stock. The agar from this alga has a gel strength of approximately $510 \mathrm{~g} \cdot \mathrm{cm}^{2}$ (Meena et al. 2008). Over-harvesting of Gr salicornia depleted the standing stock resulting in its cultivation by adopting the tube-net method. Each single tube net is filled with $400 \mathrm{~g}$ of G. salicornia seed material. The raft $(2 \times 2 \mathrm{~m}$ size $)$ consists of 15 tube nets totaling an initial biomass of $6.0 \mathrm{~kg}$ fresh weight with harvesting every $30-40$ days as thalli attain harvestable size. Harvest yields range from 14.1 to $60.62 \mathrm{~kg}$ fresh wt raft ${ }^{-1}$ (Figure 14) with seven harvests each year (Ganesan et al., unpublished).

\section{Gracilaria crassa}

Gracilaria crassa Harvey ex J. Agardh is an important agarophyte yielding agar with a gel strength of approximately $800 \mathrm{~g} \mathrm{~cm}^{-2}$ with $8 \%$ alkali treatment (Meena et al. 2008). Standing stocks of $G$. crassa are limited to a few locations along the southeast and northwest coasts of India. Recent cultivation efforts included 10 tube-nets inoculated with
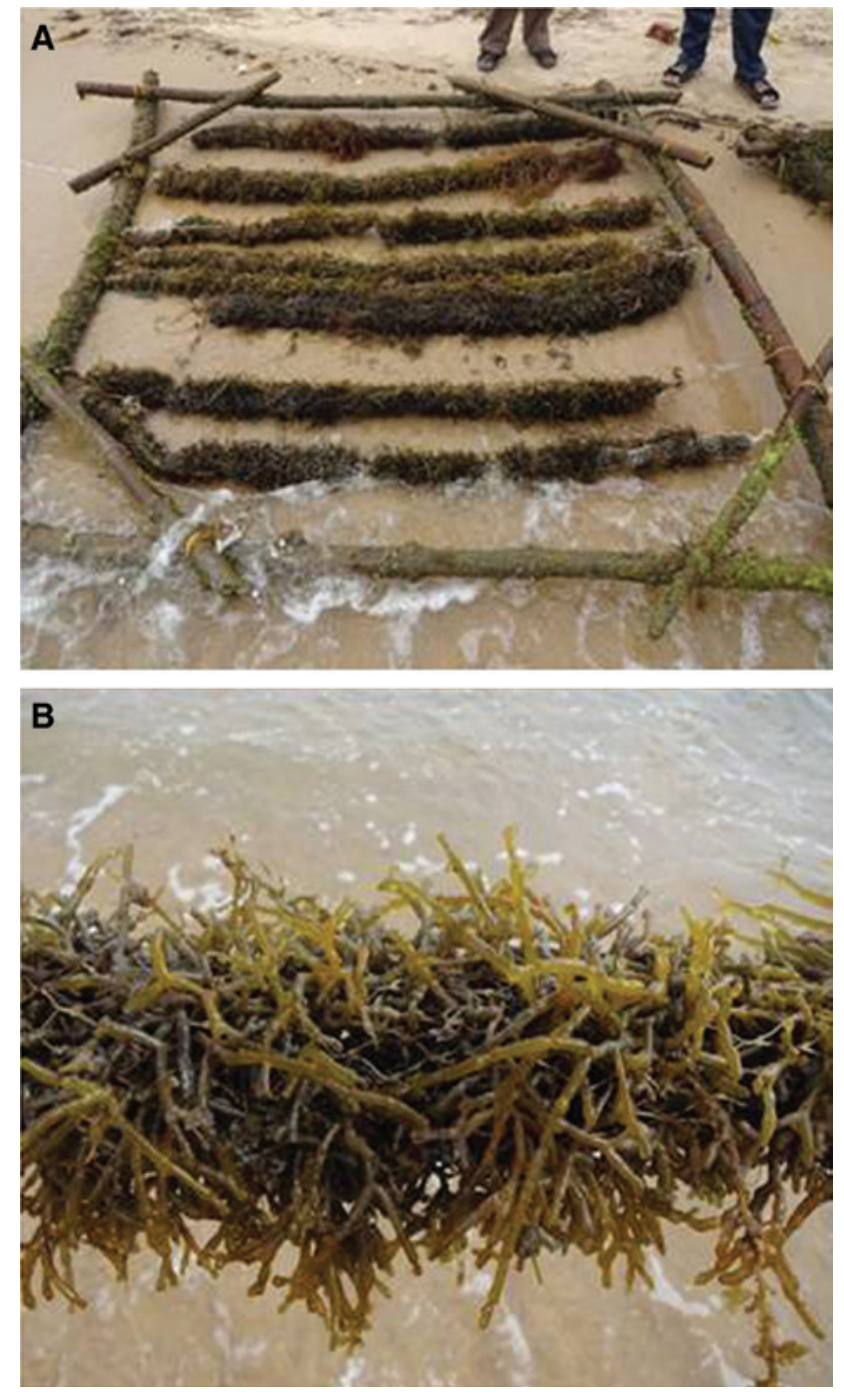

Figure 15: Gracilaria crassa cultivation.

(A) G. crassa grown on net; (B) close-up view.

$10 \mathrm{~kg}$ fresh wt $\mathrm{raft}^{-1}$. A maximum of $30 \mathrm{~kg}$ biomass was harvested at the end of a 45-day growing cycle (Figure 15).

\section{Economics of seaweed cultivation}

The bamboo raft system is the preferred method for all industrially valuable Indian seaweeds. Advantages include: raft located in sub-surface seawater column providing adequate sunlight exposure; rafts are easily handled and relocated to suitable locations free from epiphytes and grazing; and bottom nets minimize herbivore grazing of algae. Materials for making rafts (e.g. bamboo, anchor stones, polypropylene rope, etc.) are commonly available close to the farm areas. Kappaphycus alvarezii raft size is $3 \times 3 \mathrm{~m}$; 500 rafts would occupy 1 hectare. The 
raft size typically used for Gelidiella acerosa, Gracilaria edulis and Gracilaria dura cultivation is $2 \times 2$ whereby 1000 rafts can fill 1 ha. Table 1 highlights the materials required, biomass harvested and income from cultivation of each seaweed.

\section{Future directions in seaweed culture in India}

Indian seaweed cultivation dates back nearly four decades. Cultivation technologies have been developed for several industrially valuable seaweeds over the last 20 years but there are still many challenges to overcome. Challenges include the need for high-temperature-tolerant and fouling- and disease-resistant strains. Most Indian seaweed cultivation is located in near-shore waters, and to overcome inshore challenges an alternative farming strategy including expanding to offshore culture systems is recommended.

\section{Offshore cultivation}

Indian near-shore commercial cultivation of Kappaphycus alvareziii began in 2005 and the annual production reached a peak of 1490 tonnes in 2013 (Mantri et al. 2017). Nevertheless, the quantity of production is relatively low when compared with Indonesia, who produced 15 million tonnes of seaweeds in 2015 (Buschmann et al. 2017). Indian seaweed cultivation in near-shore areas faces several challenges. Expansion of cultivation grounds is a major constraint due to water use conflicts with fish landing centers and commercial fishing activities. Eutrophication due to human sewage rich in phosphate and nitrate from major municipalities and small towns has negative impacts on seaweed growth. Run-off from land-based agriculture, thermal power plants and chemical factories inundates near-shore waters and contributes to commercial cultivation challenges. Shallow, near-shore seawater temperatures often reach levels that inhibit seaweed growth. These challenges represent contributing reasons to relocate seaweed cultivation operations to offshore sites.

Offshore seaweed cultivation has several potential advantages including: elimination of space limitation as vast ocean areas are available; water use conflicts are minimized due to minimal fishing activities; and offshore waters are clean and transparent as agricultural runoff, sewage and industrialized discharges are minimized due to open ocean dispersion. Offshore algal farming has potential disadvantages including: maximum wave height of 5-10 m; current velocity of 2-3 knots; and wind speeds of $35 \mathrm{~m} \mathrm{~s}^{-1}$ all of which can damage and dislodge the farm infrastructure. Offshore farming units must be able to withstand these dynamic conditions. The development of novel, offshore seaweed farms could play a major role in generating sustainable energy from biomass. Use of special textile mats can simplify seaweed farming and substantially increase yields (Sulaiman et al. 2015). A pioneering seaweed farm was developed by a consortium of 11 companies working together in the European At-Sea project. It was successfully tested at three locations (Kassila et al. 2019). A similar initiative for large-scale offshore seaweed cultivation needs to be attempted in India.

\section{Commercial cultivation using spore based methods}

Traditional seaweed farming techniques involving vegetative propagation require a large amount of seed stock biomass. An average of $20-30 \%$ of harvested material needs to be recycled during seeding procedures. Thallus aging can be a critical challenge in vegetative propagation. Strains can lose vigor after successive generations and productivity can decrease after 2-3 years of continuous cultivation. Epiphyte colonization is another important impediment of vegetative propagation. Epiphyte associations can build after 2-3 harvests because the old plants lose their chemical defenses (He and Yarish 2007).

Alternatively, mass culture utilizing spores requires only a few grams of reproductive material. Geminating spores can generate thousands of plantlets which can be used for mass propagation. Spore-originated thalli have high polymorphism due to their origins from several different genotypes. Such diversity can enable adaptation to changes in environmental conditions. Large scale cultivation from isolated spores has been successfully developed to provide raw material for the phycocolloid industry using the carageenophytes Kappaphycus alvarezii (De Paula et al. 1999), Sarcothalia crispata (Avila et al. 1999), Gigartina skottsbergii (Buschmann et al. 2001), and agarophytes such as Gracilaria verrucosa (Oza et al. 1994), Gracilaria rex (Ramiro Rojas et al. 1996), Gracilaria chilensis (Alveal et al. 1997), Gracilaria Parvispora (Glenn et al. 1998) and Gracilariopsis bailinae (Rabanal and Azanza 1999).

Indian Gracilaria resources are dwindling due to over exploitation of Gracilaria edulis and Gracilaria salicornia by agar based industries. Gracilaria spp. typically have two diploid stages in addition to the gametophyte stage. Tetrasporophytes are similar to male and female gametophytes 
while the alternate diploid phase, cystocarps occur on the surface of the female thallus. Cystocarps produce profuse numbers of carpospores that can rapidly recruit, germinate, and grow making them ideal for commercial scale cultivation. Future cultivation of Gracilaria spp. could be successful utilizing spore based culture only.

\section{Conventional breeding method for producing vigorous strains of phycocolloid seaweeds}

The reduced value of Indian agarophyte seaweeds like Gracilaria and Gelidiella is due to the low quality agar obtained from these algae. Repeated harvests from natural stocks resulted in the loss of algal vigor. Kappaphycus alvarezii farm yields are constantly declining over time. The major challenge facing the Indian phycocolloid industry is to improve phycocolloid quality in order to penetrate international markets. Therefore, cultivation enhancement programs must be implemented for all phycocolloid yielding seaweeds to produce superior varieties with higher growth rates and increased phycocolloid yields. Indonesia's cross breeding of free moving gametes of Gracilaria strains resulted in high growth rates and increased cell wall thickness (Ginneken 2018). Development of focused breeding efforts is imperative for the industrially valuable Indian phycocolloid seaweeds.

\section{Macroalgal functional genomics}

Higher seaweed values have increased the demand for raw materials but has also highlighted the necessity for functional trait improvements. Unlike for terrestrial crops, acknowledging the need for functional trait improvements in seaweed cultivars is a recent concept. Seaweed genome sequences are essential in order to design strategies for the functional trait improvements. Terrestrial plant functional genomics contributed significantly to crop improvement by understanding their bio-architecture, physiology, regulation and metabolic activations. However, seaweed functional genomics databases are limited despite their proven economic value. Historical perspectives include: (1) the 1940s witnessed continued expansion in the applications of in vitro plant cell and tissue culture techniques but these techniques were not adapted for seaweed research and development studies until the early 1990s (Reddy et al. 2008a,b, 2010); and (2) seaweed genome editing techniques were unavailable until a recent report by Oertel et al. (2015) on developing suitable vectors and stable transformation in Ulva mutabilis. The lagging pace of seaweed genomics development can therefore be viewed as one of the bottlenecks retarding the progress of seaweed improvement programs.

Nevertheless, seaweed expression sequence tag (EST) libraries and a few transcriptome profiles have been generated for seaweeds and these facilitate understanding of regulatory mechanisms relevant to various stresses (Dittami et al. 2009, Gravot et al. 2010, Pearson et al. 2010, Dittami et al. 2011, 2012, Heinrich et al. 2012, Coelho et al. 2013). Whole genome sequences are now available for brown algae including: Ectocarpus siliculosus (Cock et al. 2010) and Saccharina japonica (Ye et al. 2015), and for the red alga Chondrus crispus (Collen et al. 2013). Such information could shed light on the novel physiological processes of seaweeds that impact on their propagation in highly dynamic oceanic conditions. Novel metabolic pathway genes of interest from commercial seaweeds include flavonoid pathway genes homologous to those in vascular plants synthesizing phenolic molecules; halide metabolism and the presence of 21 putative dehalogenases and 2 halo alkane dehalogenases; development of multi-cellularity and evolution (Cock et al. 2010); halogen metabolism; oxylipin synthesis; and microRNA and transcription factors for the development of multicellularity (Collen et al. 2013). Furthermore, understanding the genomic regulation of hydrocolloid synthesis, assembly and transport of cell wall matrices is a promising research sector. Decoding the 'language' of their biosynthesis will eventually help in improving the crop yields and extract qualities. Recently, seaweed genomic research has attracted increased global attention but India's contribution towards understanding seaweed functional genomics is negligible. Decoding seaweed functional genomics should be a research priority of India's Seaweed 2020 program. Seaweed functional genomics must develop more tools to assay the effects of genes, allowing the discovery of gene regulatory network relationships with seaweed-specific, specialized metabolic pathways. Novel metabolic engineering research endeavors may be initiated for the production of targeted specialized seaweed metabolites.

\section{Downstream process for extraction of seaweed products}

Conventional phycocolloid seaweed processors, who do not embrace biorefinery process technologies, use only $15-30 \%$ of the total dry seaweed biomass while the remaining $70-85 \%$ is degraded during the phycocolloid extraction processes or is discarded as waste streams. However, recent studies have reported that the seaweeds are rich in 
valuable metabolites, such as natural pigments, proteins, lipids, minerals and cellulose which can be extracted and utilized through biorefinery processing methodologies (Ingle et al. 2011, Baghel et al. 2015, Bikker et al. 2016, Trivedi et al. 2016, Gajaria et al. 2017).

Seaweeds have relatively low lipid contents, but their composition is rich in C18 (linoleic and alpha-linolenic) fatty acids and low in C20 PUFAs (polyunsaturated fatty acids), a combination that has been associated with the prevention of cardiovascular diseases, osteoarthritis and diabetes. The potential of the phycocolloid ulvan as a dietary fiber is supported by reports that the cell wall polysaccharide is not degraded by human gastrointestinal enzymes. This insolubility contributes to the water retention capacity of the ulvan fibers, supporting its use as a bulking agent reducing pathologies related to intestinal transit dysfunctions. Various studies (O'Sullivan et al. 2010, Tabarsa et al. 2012, Alves et al. 2013, Venkatesan et al. 2015) report that ulvan or derived oligosaccharides significantly lowered serum total cholesterol, LDL-cholesterol and reduced triglyceride levels, while they increased the levels of serum HDL-cholesterol. These preliminary results provide evidence supporting the application of ulvan or derived oligosaccharides in functional foods and feed. The gastrointestinal and lipid metabolism benefits of ulvan are in addition to its immunomodulatory, antitumor, strain-specific anti-influenza activities and anticoagulant activities.

Proteins synthesized by macroalgae are known to contain all the essential amino acids (EAA), although seasonal variations in EAA concentrations are reported. Ulva lactuca has been found to possess a high protein content comparable to traditional high protein plant sources, justifying its direct use in human or animal nutrition (Fleurence 1999, Bleakley and Hayes 2017).

Cellulose and other polysaccharide fractions extracted from seaweeds can be converted to ethanol, levulinic acid and its derivatives, including ethyl levulinate, which can be used as a fuel additive for both diesel and biodiesel (Jeong et al. 2015, Francavilla et al. 2016, Trivedi et al. 2016). Seaweed biomass has almost no lignin, therefore conversion costs could be lower than those incurred using cellulosic biomass.

\section{Biofuel production from seaweeds}

Seaweeds are appealing potential biofuel feedstock candidates for the production of transportation fuel, as they grow rapidly and exhibit high photosynthetic light harvesting efficiency (Hannon et al. 2010). Globally, several countries including India have reported efficient conversion of macroalgae to biofuels such as bioethanol, biobutanol, biomethane and biohydrogen. Potential Indian seaweed genera for biofuel production in India include Ulva, Kappaphycus, Gracilaria, Gelidium, Sargassum, etc. (Khambhaty et al. 2012, Kumar et al. 2013, Trivedi et al. 2013, Baghel et al. 2015, Veeramuthu et al. 2017). Red algal genera including Kappaphycus, Gracilaria and Gelidium have been cultivated in India for phycocolloid production. Due to their potential for large-scale farming, these seaweeds have been examined for their biofuel production potential, utilizing their phycocolloid or cellulose content as substrates. Recently, green seaweeds, mainly Ulva sp., have also emerged as potential feedstock for biofuel production due to their high carbohydrate content, higher growth rates and lack of direct commercial utilization (Trivedi et al. 2016).

Several research groups in India are actively working on the growth engineering of seaweeds, bio-refinery techniques for extraction of value-added products and photobioreactor design for high biomass production. Biofuel production from residual biomass after extraction of valueadded bio-products from seaweeds makes the process economically viable from an industrial perspective.

Seaweeds contain both homo- and hetero-polysaccharides which require special enzymes and microbes to release and ferment hydrolyzed sugars. Metabolic modelling of biomass conversion using serial fermentation is a novel approach to enhance the overall yield of seaweed-based biofuel production. The development of new seaweed varieties with diverse genotypic and phenotypic characteristics utilizing biotechnological techniques is ongoing. Seaweed feedstock development through somatic hybridization and mutagenesis are attractive and available techniques for producing hybrid and mutant seaweed cultivars with useful proximate composition (Charrier et al. 2015, Gupta et al. 2015). Enhanced cultivars would improve seaweed yields for the production of biofuels and platform chemicals.

\section{Opportunities and challenges for establishing successful seaweed industries in India}

\section{Opportunities}

Bio-fertilizer and bio-stimulants from seaweeds have immense potential in the Indian agriculture sector. Seaweed bio-stimulants increase crop yields and quality, 
reduce use of chemical fertilizers and help improve the soil fertility. India imports seaweed bio-stimulants made from Ascophyllum, Macrocystis and Kappaphycus worth US \$25-30 million annually from Canada, Norway, Indonesia, Philippines and China. There are opportunities to promote indigenous seaweed-based technology for the production of bio-stimulants. Sargassum spp. Kappaphycus alvarezii and Gracilaria spp. are excellent sources of bio-stimulants (Rathore et al. 2008, Zodape et al. 2008, 2009, 2010). Promoting indigenous seaweeds for bio-stimulants will reduce the fertilizer subsidy burden of the Indian exchequer.

Seaweeds have the potential to be used in a broad spectrum of products such as: food, biofuels, chemicals, cosmetics, medicines, etc. The National Bio-fuel Policy of India (2018) targeted 20\% blending of biofuels by 2030 . It is estimated that, if 460 million tons of fresh seaweed biomass per year could be harvested from a 10 million hectare area (corresponding to about 5\% of total EEZ of India), it could generate 6.66 billion liters of bioethanol, which would meet the targeted petrol blending by 2030 in India. Industrial production of biofuel from seaweeds needs to be given top priority.

India's traditional food practices are different from other Asian seaweed consuming nations. Although 30\% of the Indian population lives close to the sea, people are not accustomed to eating seaweed. Formulation of a wide variety of recipes by food technology institutes for adaptation to Indian palates and popularization through social media are needed for promoting seaweed-based foods in India. International collaboration for processing and preparation of seaweed-based foods should be established with the Southeast Asian countries where consumption of seaweed food is popular.

Seaweeds have tremendous business potential for generating revenue and jobs in bioactive and cosmetic sectors as they possess anti-ageing, anti-oxidant and moisturizing properties (Bedoux et al. 2014). However, such applications are not yet developed at the industrial level in India and so an initiative to do so needs to be given priority. Seaweeds with high pharmaceutical and cosmetic applications need to be identified and cultivated at large scale through industrial collaborations. Identifying suitable cultivable and scalable seaweed strains for pharmaceutical and cosmetic applications should be undertaken by an industrial public sector collaboration.

\section{Challenges}

Several cultivation technologies have been developed through significant Indian research and development efforts, and commercial seaweed farming is being carried out using floating rafts (Mantri et al. 2017) along the southeast coast of India. Such structures are suitable for near-shore waters where low tidal amplitude and minimal tidal influences persist. However, a major portion of the Indian coastline is exposed to the open sea and has high tidal amplitudes. Recently, CSIR-CSMCRI has successfully developed tube net method for Kappaphycus alvarezii and Gracilari dura cultivation on the Gujarat coast. Tube-net systems withstand rough sea conditions while producing good biomass yields. Several other culture systems which can withstand high water dynamics in open water areas needs to be developed through vigorous $R$ \&D efforts.

Seasonal dependency on Indian seaweed culture represents a crucial challenge needing to be overcome. Monsoonal (Southwest and Northeast monsoon) periods in India are associated with occasional occurrence of cyclones and typhoons and create high seawater turbulence and high tidal fluctuations. Cultivation during this period is restricted to seed bank preservation.

Land-based cultivation in intensively operated ponds has been done successfully for several species of Gracilaria (Friedlander and Levy 1995), Gelidium (Friedlander 2008) and Chondrus crispus (Bidwell et al. 1985). In India, seaweeds are mainly used for extracting phycocolloids and the high cost of pond-produced seaweeds may not be profitable unless the harvested seaweeds are processed for multiple products e.g. biofuel, bio-stimulants, food, cosmetics and pharmaceuticals Seaweed growers are receiving minimal prices for their harvested seaweeds due to their sale to cottage-level industries for indigenous phycocolloid extraction. Export of dry seaweeds has been banned for several decades. If the ban is lifted and export of dry seaweeds is permitted, farmers will realize higher prices for their seaweeds. Other challenges in seaweed farming affecting crop productivity and quality are crop health issues such as high temperature impacts, diseases, epibionts and grazing pressures which rely on R\&D efforts to reduce or eliminate.

Acknowledgments: The authors are grateful to the Council of Scientific and Industrial Research, New Delhi; Department of Biotechnology, New Delhi; Ministry of New and Renewable Energy, New Delhi; Gulf of Mannar Biosphere Reserve Trust, Government of Tamil Nadu and other funding agencies for the R \& D support. They thank Dr. Amitava Das, Director, CSMCRI for encouragement. They are also thankful to Professor L. Kannan, former Director, Marine Biology Department, Annamalai University and Dr. Ian Neish, Sea6 Energy for their help in correcting the manuscript. This publication has CSIR-CSMCRI registration no. 219/18. 
Conflict of interest statement: The authors declare that they have no conflicts of interest regarding this article.

\section{References}

Alveal, K., H. Romo, C. Werlinger and E.C. Oliveira. 1997. Mass cultivation of the agar-producing alga Gracilaria chilensis (Rhodophyta) from spores. Aquaculture 148: 77-83.

Alves, A., R.A. Sousa and R.L. Reis. 2013. A practical perspective on ulvan extracted from green algae. J. Appl. Phycol. 25: 407-424.

Anon. 2012. Final Report, Council of scientific and industrial research. Ministry of Science \& Technology, Rafi Marg, New Delhi. pp. 30.

Anon. 2017. Annual Report, Department of agriculture, cooperation and farmers welfare. Ministry of Agriculture and Farmers Welfare, Krishi Bhavan, New Delhi. pp. 190.

Avila, M., E. Ask, B. Rudolph, M. Nunez and R. Norambuena. 1999. Economic feasibility of Sarcothalia (Gigartinales, Rhodophyta) cultivation. Hydrobiologia 398/399: 435-442.

Baghel, R.S., N. Trivedi, V. Gupta, A. Neori, C.R.K. Reddy, A. Lali and B. Jha. 2015. Biorefining of marine macroalgal biomass for production of biofuel and commodity chemicals. Green Chem. 17: 2436-2443.

Bedoux, G., K. Hardouin, A.S. Burlot and N. Bourgougnon. 2014. Bioactive compounds from seaweeds: cosmetic applications and future development. Adv. Bot. Res. 71: 345-379.

Bidwell, R., J. McLachlan and N. Lloyd. 1985. Tank cultivation of Irish moss, Chondrus crispus Stackh. Bot. Mar. 28: 87-97.

Bikker, P., M.M. Krimpen, P. Wikselaar, B. Houweling-Tan, N. Scaccia and J.W. Hal. 2016. Biorefinery of the green seaweed Ulva lactuca to produce animal feed, chemicals and biofuels. J. Appl. Phycol. 28: 3511-3525.

Bleakley, S and M. Hayes. 2017. Algal Proteins: extraction, application, and challenges concerning production. Foods 6: 33-35.

Boergesen, F. 1928. On Rosenvingea stellata, a new Indian alga and on an interesting littoral algal vegetation in which this species is characteristic constituent. Dansk Botnisk Arkiv. 5: 511.

Buschmann, A., J. Correa, R. Westermeier, M. Paredes, D. Aedo, P. Potin, G. Aroca, J. Beltran and M. Hernandez-Gonzalez. 2001. Cultivation of Irish moss (Gigartinales, Rhodophyta): recent advances and challenges for the future. J. Appl. Phycol. 13: 255-566.

Buschmann, A.H., C. Camusa, J. Infanteb, A. Neori, Á. Israele, M.C. Hernández, G. Sandra, V. Peredaa, J.L. Gomez-Pinchettic, A. Golbergf, N. Tadmor-Shalev and A.T. Critchley. 2017. Seaweed production: overview of the global state of exploitation, farming and emerging research activity. Eur. J. Phycol. 52: 391-406.

Charrier, B., E. Rolland, V. Gupta and C.R.K. Reddy. 2015. Production of genetically and developmentally modified seaweeds: exploiting the potential of artificial selection techniques. Front. Plant Sci. 6: 127.

Coelho, S.M., N. Simon, S. Ahmed, J.M. Cock and F. Partensky. 2013. Ecological and evolutionary genomics of marine photosynthetic organisms. Mol. Ecol. 22: 867-907.

Cornish, M., A.T. Critchley and O. Mouritsen. 2017. Consumption of seaweeds and the human brain. J. Appl. Phycol. 29: 2377- 2398.
Craigie, J.S.J. 2011. Seaweed extract stimuli in plant science and agriculture. J. Appl. Phycol. 23: 371-393.

Cock, J.M., L. Sterck, P. Rouze, D. Scornet, A.E. Allen and G. Amoutzias. 2010. The Ectocarpus genome and the independent evolution of multi cellularity in brown algae. Nature 465: 617-621.

Collen, J., B. Porcel, W. Carre, S.G. Ball, C. Chaparro and T. Tonon. 2013. Genome structure and metabolic features in the red seaweed Chondrus crispus shed light on evolution of the Archaeplastida. PNAS USA 110: 5247-5252.

De Paula, E., R. Lima Pereira and M. Ohno. 1999. Strain selection in Kappaphycus alvarezii var alvarezii (Solieriaceae, Rhodophyta) using tetraspore progeny. J. Appl. Phycol. 11: 111-121.

Dittami, S.M., D. Scornet, J.L. Petit, B. Segurens, C. Da Silva and E. Corre. 2009. Global expression analysis of the brown alga Ectocarpus siliculosus (Phaeophyceae) reveals large scale reprogramming of the transcriptome in response to abiotic stress. Genome Biol. 10: 1-10.

Dittami, S.M., A. Gravot, D. Renault, S. Goulitquer, A. Eggert and A. Bouchereau. 2011. Integrative analysis of metabolite and transcript abundance during the short term response to saline and oxidative stress in the brown alga Ectocarpus siliculosus. Plant Cell Environ. 34: 629-642.

Dittami, S.M., A. Gravot, S. Goulitquer, S. Rousvoal, A.F. Peters and A. Bouchereau. 2012. Towards deciphering dynamic changes and evolutionary mechanisms involved in the adaptation to low salinities in Ectocarpus (brown algae). Plant J. 71: 366-377.

Eswaran, K., P.K. Ghosh and O.P. Mairh. 2002. Experimental field cultivation of Kappaphycus alvarezii (Doty) Doty ex Silva at Mandapam region. Seaweed Res. Utiln. 24: 67-72.

FAO. 2014. The State of World Fisheries and Aquaculture. Food and Agriculture Organization of the United Nations. pp. 1-223.

FAO. 2018. The State of World Fisheries and Aquaculture. Food and Agriculture Organization of the United Nations. pp. 1-210.

Fleurence, J. 1999. Seaweed proteins: Biochemical, nutritional aspects and potential uses. Trends Food Sci. Technol. 10: 25-28.

Francavilla, M., S. Intini, L. Luchetti and R. Luque. 2016. Tunable microwave-assisted aqueous conversion of seaweed-derived agarose for the selective production of 5-hydroxymethyl furfural/levulinic acid. Green Chem. 18: 5971-5977.

Friedlander, M. 2008. Advances in cultivation of Gelidiales. J. Appl. Phycol. 20: 451-456.

Friedlander, M. and I. Levy. 1995. Cultivation of Gracilaria in outdoor tanks and ponds. J. Appl. Phycol. 7: 315-324.

Gajaria, T.K., P. Suthar, R.S. Baghel, N.B. Balar, P. Sharnagat, V.A. Mantri and C.R.K. Reddy. 2017. Integration of protein extraction with a stream of byproducts from marine macroalgae: a model forms the basis for marine bioeconomy. Bioresour. Technol. 243: 867-873.

Ganesan, M., S. Thiruppathi and B. Jha. 2006. Mariculture of Hypnea musciformis (Wulfen) Lamourex in the south east coast of India. Aquaculture 256: 201-211.

Ganesan, M., S. Thiruppathi, K. Eswaran, C.R.K. Reddy and B. Jha. 2009. Cultivation of Gelidiella acerosa in the open sea on the Southeastern coast of India. Mar. Ecol. Progr. Ser. 382: 49-57.

Ganesan, M., N. Sahu and K. Eswaran. 2011. Raft culture of Gracilaria edulis in open sea along the southeastern coast of India. Aquaculture 321: 145-151.

Ganesan, M., R. Meena, A.K. Siddhanta, K. Selvaraj and K. Chithra. 2015a. Culture of red alga Sarconema filiforme in offshore 
waters and hybrid carrageenan from cultivated seaweed. J. Appl. Phycol. 27: 1549-1559.

Ganesan, M., C.R.K. Reddy and B. Jha. 2015b. Impact of cultivation on growth rate and agar content of Gelidiella acerosa (Gelidiales, Rhodophyta). Alg. Res. 12: 398-404.

Ganesan, M., K. Eswaran and C.R.K. Reddy. 2017. Farming of agarophytes in India - a long time sustainability for the industry and preserving wild stocks. J. Appl. Phycol. 29: 2239-2248.

Ginneken, V. 2018. Seaweed biotechnology to combat desertification. Adv. Biochem. Biotechnol. 1-5.

Glenn, E.P., D. Moore, J.J. Brown, R. Tanner, K. Fitzsimmons, M. Akutigawa and S. Napolean. 1998. A sustainable culture system for Gracilaria parvispora (Rhodophyta) using sporelings, reef grow out and floating cages in Hawaii. Aquaculture 165: 221-232.

Gravot, A., S.M. Dittami, S. Rousvoal, R. Lugan, A. Eggert and J. Collen. 2010. Diurnal oscillations of metabolite abundances and gene analysis provide new insights into central metabolic processes of the brown alga Ectocarpus siliculosus. New Phytol. 188: 98-110.

Gupta, V., P. Kumari and C.R.K. Reddy. 2015. Development and Characterization of Somatic Hybrids of Ulva reticulata Forsskål $(x)$ Monostroma oxyspermum (Kutz.) Doty. Front. Plant Sci. 6: 3-9.

Hafting, J., J. Craigie, D. Stengel and A.T. Critchley. 2015. Prospects and challenges for industrial production of seaweed bioactives. J. Phycol. 51: 821-837.

Hannon, M., J. Gimpel, M. Tran, B. Rasala and S. Mayfield. 2010. Biofuels from algae: challenges and potential. Biofuels 1: 763-784.

He, P. and C. Yarish. 2007. The developmental regulations of mass culture of free living conchocelis for commercial net seeding of Porphyra leucosticte from North East America. Aquaculture. 257: 373-381.

Heinrich, S., K. Valentin, S. Frickenhaus, U. John and C. Wiencke. 2012. Transcriptomic analysis of acclimation to temperature and light stress in Saccharina latissima (Phaeophyceae). PLoS One 7: 15-18.

Ingle, K., E. Vitkin, A. Robin, Z. Yakhini, D. Mishori and A. Golberg. 2011. Macroalgae biorefinery from Kappaphycus alvarezii: conversion modelling and performance prediction for India and Philippines as examples. Bioenergy Res. 11: 22-28.

Iyengar, M.O.P. 1927. Krusadai island flora. Bulletin of Madras Government Museum. New Ser. Nat. Hist. Sect. 1: 185-188.

Jeong, G.T., C.H. Ra, K.Y. Hong, J.K. Kim, I.S. Kong, S.K. Kim and D.H. Park. 2015. Conversion of red-algae Gracilaria verrucosa to sugars, levulinic acid and 5-hydroxymethylfurfural. Bioprocess Biosyst. Eng. 38: 207-217.

Jha, B., C.R.K. Reddy, M.C. Thakur and M.U. Rao. 2009. Seaweeds of India: the diversity and distribution of seaweeds of the Gujarat coast. Springer, Dordrecht. pp. 198.

Kaliaperumal, N and S. Kalimuthu. 1997. Seaweed potential and its exploitation in India. Seaweed Res. Utiln. 19: 33-40.

Kassila, J., H. Nhhala, T. Givernaud, M. Monsouri, O. Yazami, A. Abrehouch, A. Mosfioui and M. Idahala. 2019. Opportunities for the development of seaweed farming as a supplementary income for small-scale fishermen in Nador lagoon: experimental cultivations of Gracilaria gracilis (Stackhouse). Med. Far. 2: 12-26.

Khambhaty, Y., K. Modi, M.R. Gandhi, S. Thampy, P. Maiti and H. Brahmbhatt. 2012. Kappaphycus alvarezii as a source of bioethanol. Bioresour. Technol. 103: 180-185.
Kim, J.K., C. Yarish, E.K. Hwang, M. Park and Y. Kim. 2017. Seaweed aquaculture: cultivation technologies, challenges and its ecosystem services. Algae 32: 1-13.

Krishnamurthy, V. 1957. The genus Bangiopsis Schmitz from South India. Phytomorphology 7: 102-112.

Krishnamurthy, V. 1971. Seaweed resources of India and their utilization. Seaweed Res. Utiln. 1: 55-67.

Krishnan, M and R. Narayanakumar. 2010. Socio-economics of seaweed farming in India. Central Marine Fisheries Research Institute, Kochi, India, Special Bulletin No. 104: 103.

Kumar, S., R. Gupta, G. Kumar, D. Sahoo and R.C. Kuhad. 2013. Bioethanol production from Gracilaria verrucosa, a red alga, in a biorefinery approach. Bioresour. Technol. 135: 150-156.

Levitt, G.J., R.J. Anderson, C.J.T. Boothroyd and F.A. Kemp. 2002. The effects of kelp harvesting on its re growth and the un destroyed benthic community at Danger Point, South Africa, and a new method of harvesting kelp fronds. S. Afr. J. Mar. Sci. 24: 71-85.

Mantri, V.A., K. Eswaran, M. Shanmugam, M. Ganesan, V. Veeragurunathan, A. Seth and C.R.K. Reddy. 2017. An appraisal of commercial farming of Kappaphycus alvarezii in India: Success in diversification of livelihood and prospects. J. Appl. Phycol. 29: 335-357.

Meena, R., K. Prasad, M. Ganesan and A.K. Siddhanta. 2008. Superior quality of agar from Gracilaria species (Gracilariales, Rhodophyta) collected from Gulf of Mannar, India. J. Appl. Phycol. 20: 397-402.

Migné, A., C. Golléty and D. Davoult. 2014. Effect of canopy removal on a rocky shore community metabolism and structure. Mar. Biol. 162: 449-457.

Oertel, W., T. Wichard and A. Weissgerber. 2015. Transformation of Ulva mutabilis (Chlorophyta) by vector plasmids integrating into the genome. J. Phycol. 51: 963-979.

O’Sullivan, L., B. Murphy, P. McLoughlin, P. Duggan, P.G. Lawlor, H. Hughes and G.E. Gardiner. 2010. Prebiotics from marine macro algae for human and animal health applications. Mar. Drugs 8 : 2038-2064.

Oza, R.M. and S.H. Zaidi. 2001. A revised checklist of Indian marine algae. CSMCRI Publication, Bhavnagar, India. pp. 296.

Oza, R., A. Tewari, M. Rajyaguru and S. Goswamy. 1994. Laboratory and field culture of marine red alga Gracilaria verrucosa (Gracilariaceae, Rhodophyta). Ind. J. Mar. Sci. 23: 157-161.

Patel, J.B., B.V. Gopal, V.R. Nagulan, K. Subbaramaiah and P.C. Thomas. 1986. Experimental field cultivation of Gelidiella acerosa at Ervadi in India. Proc. Symp. Coast. Aquacult. 4: 1342-1343.

Pearson, G.A., G. Hoarau, A. Lago-Leston, J.A. Coyer, M. Kube and R. Reinhardt. 2010. An expressed sequence tag analysis of the intertidal brown seaweeds Fucus serratus (L.) and F. vesiculosus (L.) (Heterokontophyta, Phaeophyceae) in response to abiotic stressors. Mar. Biotechnol. 12: 195-213.

Periyasami, C., P. Anantharaman and T. Balasubramanian. 2014. Social upliftment of coastal fisher women through seaweed (Kappaphycus alvarezii (Doty) Doty) farming in Tamil Nadu, India. J. Appl. Phycol. 26: 775-781.

Periyasami, C., P. Anantharaman and P.V. Subba Rao. 2015. Experimental farming of Kappaphycus alvarezii (Doty) Doty with income estimates at different sites in the Mandapam region, Palk Bay, southeast coast of India. J. Appl. Phycol. 27: 935-944.

Phillippi, A., K. Tran and A. Perna. 2014. Does intertidal canopy removal of Ascophyllum nodosum alter the community structure beneath? J. Exp. Mar. Biol. Ecol. 461: 53-60. 
Prasad, K., A.K. Siddhanta, M. Ganesan, B.K. Ramawat, B. Jha and P.K. Ghosh. 2007. Agars of Gelidiella acerosa of west and southeastern coast of India. Bioresour. Technol. 98: 1907-1915.

Rabanal, S.F. and R.V. Azanza. 1999. Outplanting of laboratory-generated carposporelings of Gracilariopsis bailinae off northern Philippines. Proceedings of the Sixteenth International Seaweed Symposium. Hydrobiologia 99: 463-468.

Raju, P.V. and P.C. Thomas. 1971. Experimental field cultivation of Gracialria edulis (Gmel.) Silva. Bot. Mar. 14: 71-75.

Ramiro Rojas, H., M. Nelson Leon and O. Ramiro Rojas. 1996. Practical and descriptive techniques for Gelidium rex (Gelidiales, Rhodophyta) culture. Hydrobiologia 326/327: 367-370.

Rathore, S.S., D.R. Chaudhary, G.N. Boricha, A. Ghosh, B.P. Bhatt, S.T. Zodape and J.S. Patolia. 2008. Effect of seaweed extract on the growth, yield and quality of soybean (Glycine max) under rain fed conditions. S. Afr. J. Bot. 75: 351-355.

Reddy, C.R.K., B. Jha, Y. Fujita and M. Ohno. 2008a Seaweed micro propagation techniques and their potentials: an overview. J. Appl. Phycol. 20: 609-617.

Reddy, C.R.K., M.K. Gupta, V.A. Mantri and B. Jha. 2008b. Seaweed protoplasts: status, biotechnological perspectives and needs. J. Appl. Phycol. 20: 619-632.

Reddy, C.R.K., V. Gupta and B. Jha. 2010. Developments in biotechnology of red algae. In: J. Seckbach and D.J. Chapman, (eds) Red algae in the genomic age. Springer, Dordrecht. pp. 307-341.

Subbaramaiah, K. and R. Banumathi. 1992. A preliminary note on the raft cultivation of Gelidiella acerosa. Phykos 31: 1-5.

Subbaramaiah, K. and P.C. Thomas. 1995. Raft Cultivation of Gracialria edulis (Gmel.) Silva. Proc. Indian Acad. Sci. (Plant Sci.) 100: 123-127.

Subbaramaiah, K., K. Rama Rao and M.R.P. Nair. 1975. Cultivation of Gelidiella acerosa. Salt. Res. Indus. 11: 33-36.

Sulaiman, 0.O., A.S.A. Kader, A. Magee and K. Othman. 2015. Mooring analysis of offshore aquaculture oceanic farming platform for seaweed. J. Coast. Zone Manage. 18: 366-399.

Tabarsa, M., J.H. Han, C.Y. Kim and S.G. You. 2012. Molecular characteristics and immune modulatory activities of water-soluble sulphated polysaccharides from Ulva pertusa. J. Med. Food. 15: 135-144.

Thivy, F. 1948. A revision of the genus Turbinaria Lamax. In: Proceed ings of the Thirty-fifth Indian Science Congress, Patna.

Thompson, S.A., H. Knoll, C.A. Blanchette and K.J. Nielsen. 2010. Population consequences of biomass loss due to commercial collection of the wild seaweed Postelsia palmaeformis. Mar. Ecol. Progr. Ser. 413: 17-31.

Trivedi, N., V. Gupta, C.R.K. Reddy and B. Jha. 2013. Enzymatic hydrolysis and production of bioethanol from common macrophytic green alga Ulva fasciata Delile. Bioresour. Technol. 150: 106-112.

Trivedi, N., R.S. Baghel, J. Bothwell, V. Gupta, C.R.K. Reddy, A.M. Lali and B. Jha. 2016. An integrated process for the extraction of fuel and chemicals from marine macroalgal biomass. Sci. Rep. 6: 307-328.

Umamaheswara Rao, M. 1969. Liagora visakhapatnamensis, a new species from India. Hydrobiologia. 33: 201-208.

Veeragurunathan, V., K. Eswaran, K. Saminathan, V.A. Mantri, J. Malarvizhi, G. Ajay and B. Jha. 2015. Feasibility of Gracilaria dura cultivation in the open sea on the South eastern coast of India. Aquaculture 438: 68-74.
Veeramuthu, A.K., R.S. Mohd, S. Zainal, S.K. Pandian, T.C. Cheng, E. Sanniyasi, S. Veeraperumal and N.A. Farid. 2017. Production of liquid biofuels (biodiesel and bioethanol) from brown marine macroalgae Padina tetrastromatica. Energ. Conver. Manage. 135: 351-361.

Venkatesan, J., B. Lowe, S. Anil, P. Manivasagan, A. Kheraif, K.H. Kang and S.K. Kim. 2015. Seaweed polysaccharides and their potential biomedical applications. Starch 67: 381-390.

Ye, N., X. Zhang, M. Miao, X. Fan, Y. Zheng, D. Xu. 2015. Saccharina genomes provide novel insight into kelp biology. Nat. Commun. 6: 6986-6991.

Zodape, S.T., V.J. Kawarkhe, J.S. Patolia and A.D. Warade. 2008. Effect of liquid seaweed fertilizer on yield and quality of Okra (Abelmoschus esculentus). J. Sci. Ind. Res. 67: 1115-1117.

Zodape, S.T., S. Mukherjee, M.P. Reddy and D.R. Chaudhary. 2009. Effect of Kappaphycus alvarezii (Doty) Doty ex.Silva extract on grain quality, yield and some yield components of wheat (Triticum aestivum L). Int. Plant Prod. 3: 97-101.

Zodape, S.T., S. Mukhopadhyay, K. Eswaran, M.P. Reddy and J. Chikara. 2010. Enhance yield and nutritional quality in green gram (Phaseolus radiata L) treated with seaweed Kappaphycus alvarezii extract. J. Sci. Indust. Res. 69: 468-471.

Article note: This article is part of the special issue series of Botanica Marina: Seaweed resources of the world: a 2020 vision, which has started publication in Botanica Marina 2019, vol. 62, issue 3. The series will be guest-edited by Alan T. Critchley, Anicia Hurtado, Leonel Pereira, Melania Cornish, Danilo Largo and Nicholas Paul.

\section{Bionotes}

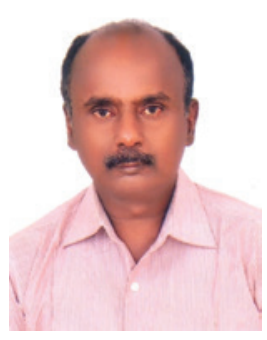

Meenakshisundaram Ganesan

Marine Algal Research Station, Division of Biotechnology and Phycology, CSIRCentral Salt and Marine Chemicals Research Institute, Mandapam Camp 623519, India ganesan@csmcri.res.in

Meenakshisundaram Ganesan, Principal Scientist in CSIR-CSMCRIMarine Algal Research Station, Mandapam, India has 3 decades of seaweed cultivation experience. He developed commercial, open sea cultivation technologies for Gelidiella acerosa, Gracilaria edulis, Gracilaria salicornia (agarophytes); and Hypnea musciformis and Sarconema filfiforme (carrageenanophytes). Dr. Ganesan is currently working on developing enhanced, Gracilaria germ plasm. He has published 66 research papers in $\mathrm{SCl}$ journals, 1 patent and licensed 1 seaweed cultivation technology. 


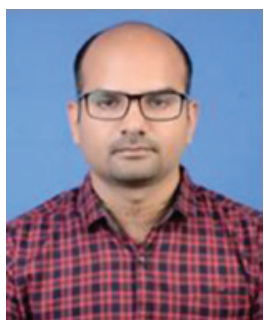

Nitin Trivedi

DBT-ICT-Centre for Energy Biosciences, Institute of Chemical Technology, Matunga, Mumbai 400019, India

Nitin Trivedi is an assistant professor at DBT-ICT Centre for Energy Biosciences, Institute of Chemical Technology, Mumbai, India. Dr. Trivedi's expertise is seaweed biotechnology (phycology); he studied seaweeds for biofuel, bio-refinery, and bio-chemicals production. Presently, Dr. Trivedi is working on seaweed cultivation engineering, seaweed mediated bioremediation and high value seaweed-based products for agriculture, nutraceutical and biomedical applications. He produced 17 publications in $\mathrm{SCl}$ journals, two book chapters and two patents. He has received several national and international fellowships/awards.

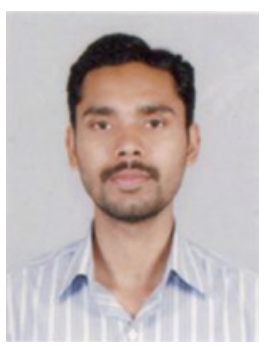

\section{Vishal Gupta}

Biological Oceanography Division, CSIR-

National Institute of Oceanography,

Dona Paula, Goa 403004, India

Vishal Gupta is an experienced researcher working on seaweed cellular biotechnology including cultivar enhancement via somatic hybridization. Additional efforts include: modelling lab-based macroalgal seed nursery, the de novo transcriptomics and untargeted metabolomics study on Ulva for desiccation and submergence tolerance. Currently he is determining the evolutionarily conserved traits between seaweeds, aquatic plants and terrestrial crops in an attempt to develop land-based crops exhibiting salt, desiccation or submergence tolerance.

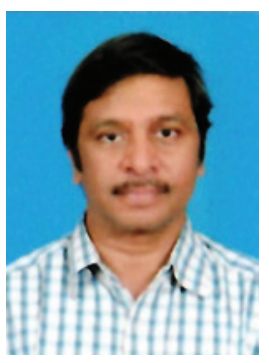

\section{S. Venu Madhav}

Divine Chemtec Ltd., Visakhapatnam Special Economic Zone, Duvvada, Visakhapatnam 530049, India

Venu Madhav, Ph.D. (Chemical Engineering), M.Eng. (Energy Technology), B.Tech. (Mechanical Engineering), is currently working as Senior Vice President - Biofuels in Divine Chemtec Ltd, a commercial biodiesel and refined glycerine production plant based on Desmet Ballestra technology. His responsibilities include plant operation, maintenance, control systems and QA/QC. He headed a team of engineers and scientists developing new technologies producing second generation biofuels and another team designed, constructed and operated an indigenously developed catalytic depolymerization pilot plant.

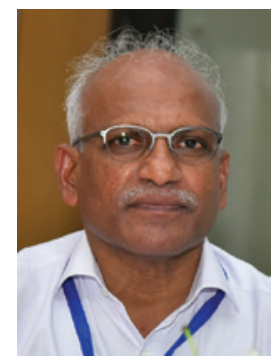

Chennur Radhakrishna Reddy

DBT-ICT-Centre for Energy Biosciences, Institute of Chemical Technology, Matunga, Mumbai 400019, India crkcsmcri@gmail.com

Chennur Radhakrishna Reddy is currently the DBT Energy Biosciences Chair at DBT-ICT Centre for Energy Biosciences, Institute of Chemical Technology, Mumbai, India. His research contributions include seaweed cellular biotechnology and marine macroalgal biorefinery technologies. Dr. Reddy's distinguished record includes authoring $80+$ publications in $\mathrm{SCl}$ journals of high repute, 18 book chapters, 3 patents and two authored and one edited books. His research works have contributed to the advancement of phycological research at international level.

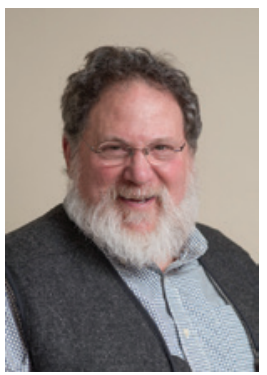

\section{Ira A. Levine}

University of Southern Maine, Lewiston, ME 04240, USA

Ira A. Levine, Ph.D. is a tenured Professor of Natural and Applied Sciences at the University of Southern Maine, President and Board Chair of the Algae Foundation, and the CEO of Algal Aquaculture Professionals, LLC. Dr. Levine was: selected as the 2017-2018 University of Southern Maine Trustee Professor; awarded 2016-2017 U.S. State Department's Distinguished Chair Fulbright and the 2009-2010 U.S. State Department's Fulbright New Century Scholar. In 2007-2008 he was a visiting professor of biology at Duke University. Dr. Levine combines 33 years of applied and basic research in the physiological ecology and cultivation of algae, aquatic farming management, and aquaculture engineering. His farming experience includes open-ocean and pond cultivation in Canada, China, Indonesia, Japan, Malaysia, Philippines, and USA (Hawaii, Florida, and Maine). Current efforts include algal cultivar enhancement for biofeeds, human nutraceuticals and cosmaceuticals, fine chemicals and algal-based biofuels. 